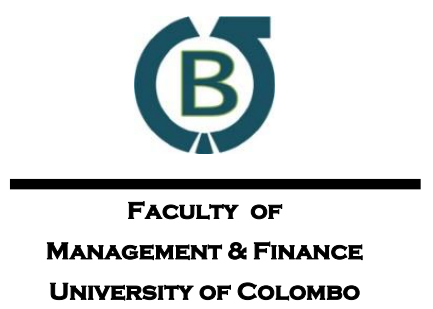

\title{
Diversity in Estimates of the Impact of Intellectual Capital on Firm Performance Created by Varied Adoptions of VAIC Method
}

\author{
Sampath Kehelwalatenna ${ }^{a} \bowtie$, Gamini Premaratne $^{\mathrm{b}}$ \\ ${ }^{a}$ Department of Accounting, University of Colombo, Sri Lanka \\ ${ }^{b}$ UBD School of Business and Economics, Universiti Brunei Darussalam, Brunei
}

\begin{abstract}
Value Added Intellectual Coefficient (VAIC) method has become the most efficient method for measuring intellectual capital (IC). However, there are inconsistencies in the mechanism of adopting the VAIC method to measure IC, thus questioning the robustness of established relationships between IC and firm performance. Therefore, this study attempts to examine the diversity in estimates of the impact of IC on firm performance as a result of adopting the VAIC method in a diverse manner. The study also proposes a modification to the basic VAIC method to eliminate its key limitation. Findings of the study indicate that there are differences in the estimates of the impact of IC on firm performance as a result of varied VAIC adoptions. The proposed modification to the basic VAIC method incorporates theoretically agreed value compositions of IC (human capital, structural capital and relational capital) replacing traditional value compositions (human capital and structural capital) in the basic VAIC method.
\end{abstract}

Keywords: Firm Performance, Intellectual Capital, Measuring Intellectual Capital, VAIC

Received:

25 February 2019
Accepted revised version: 16 May 2019
Published:

30 June 2019

Suggested citation: Kehelwalatenna, S. \& Premaratne, G. (2019). Diversity in estimates of the impact of intellectual capital on firm performance created by varied adoptions of VAIC method. Colombo Business Journal, (10)1, 66-113.

DOI: http://doi.org/10.4038/cbj.v10i1.43

(C) 2019 The Authors. This work is licenced under a Creative Commons Attribution 4.0 International Licence which permits unrestricted use, distribution, and reproduction in any medium, provided the original work is properly cited.

$凶$ sampathk@dac.cmb.ac.lk (iD) https://orcid.org/0000-0001-5702-2364 


\section{Introduction}

In the present global economy, intellectual capital (IC) is progressively being acknowledged as a vital constituent of organisational value (Alhassan \& Asare, 2016). The impetus for this awareness is a sequence of challenges in the knowledgebased corporate setting that motivates firms to invest in IC, given that it has become a key driver of productivity (Goh \& Lim, 2004). IC represents the knowledge, experience, intellectual property, and information that can be put to use to create wealth. In many instances, IC appears to be vital for decision making both within the firm and external stakeholders (Alhassan \& Asare, 2016). Novel theories of strategic management such as the Resource-based View, the Competencies and Capabilitiesbased View and the Knowledge-based View of the firm are improving the understanding of the nature and importance of IC as a strategic resource (Bontis, Janosevic, \& Dzenopoljac, 2015). As a result of a higher IC recognition, researchers are also keen to assess its impact on companies' business performance (Morariu, 2014). Regarding this, past studies (i.e. Hasan, Mohammad, \& Alam, 2017; Linda, Rasyid, \& Megwati, 2017; Soetanto \& Liem, in press) have found that IC helps in creating competitive advantages and superior performance for modern business organisations in a sustainable manner.

A paramount challenge confronted by IC practitioners and researchers is identifying the value of IC accurately. According to Zeghal and Maaloul (2010), the intangible nature of IC creates difficulties to measure it. Likewise, Abdulsalam, AlQaheri, and Al-Khayyat (2011) and Zhicheng, Zhuoer, Shing, and Wah (2016) state that finding an appropriate and universally accepted measuring technique for IC is still difficult. Chen, Cheng, and Hwang (2005), Nazari and Herremans (2007) and Tan, Plowman, and Hancock (2007) have emphasised that IC measures are still in an exploratory stage and a coherent measuring technique for IC has not been formulated yet. However, the Value Added Intellectual Coefficient (VAIC) method has gained recognition as the most efficient (Chan, 2009), and widely adopted (Zhicheng et al., 2016; Yilmaz \& Acar, 2018) measure amongst an array of measures (see Table 1) available to value IC.

Resource-based scholars contend that firm level factors account for a greater variance in firm performance than industry or country level factors (Hansen \& Wernerfelt, 1989; Rumelt, 1991 as cited in Moon \& Lado, 2000). Resource-based View equals an organisation to the resources it owns, and resources are divided into two categories as tangible and intangible. Researchers have attempted to establish the relationship between IC and performance of the firm by assuming that firm 
performance is a function of hard-to-copy, firm-specific and idiosyncratic resources. A significant number of such research work have reported a positive relationship between IC and firm performance (for example, Bontis, Keow \& Richardson, 2000; Bornemann, 1999; Calisir, Gumussoy, Bayraktaroglu \& Deniz, 2010; Chu, Chan, \& Wu, 2011; Clarke, Seng, \& Whiting, 2011; Dumay \& Tull, 2007; Ghosh \& Mondal, 2009; Ghosh \& Wu, 2007; Yalama \& Coskun, 2007; Zeghal \& Maaloul, 2010). In contrast to the above positive relationship, Firer and Williams (2003), Kamath (2008), Maditinos, Chatzoudes, Tsairidis, and Theriou (2011), Mehralian, Rajabzadeh, Sadeh, and Rasekh (2012) and Stahle, Stahle, and Aho (2011) have documented that IC does not have a significant impact on performance. Parallel to reporting mixed results as highlighted above, the inherited contextual differences (i.e., social, political, cultural and technical) in diverse settings have been identified as reasons for such mixed results (Abeysekera, 2007; Firer \& Williams, 2003; Marr, Schiuma, \& Neely, 2004). In addition to the said contextual differences, the present study presumes that varied applications of the VAIC method to measure IC might have been partially responsible for the reported mixed results.

A closer observation of existing literature on VAIC method reveals that there are inconsistencies in the mechanism of adopting it to measure IC. Consequently, these inconsistencies may pose questions on the robustness of findings presented in past studies that used the VAIC method. This is applicable specially to the areas of comparing IC values and established associations between IC and firm performance. Moreover, it is evident that there is a number of underlying limitations of using the VAIC method, as highlighted in the IC literature. Although it is natural to have limitations in any measure, including the measures available to compute IC, they undoubtedly affect the reliability of findings of empirical studies. Considering the issues of inconsistencies in adopting the VAIC method and existence of limitations of the VAIC method highlighted in the extant IC literature, this paper develops the following research objectives:

1. To examine the diversity in estimates of the impact of IC on firm performance created by varied adoptions of VAIC method; and

2. To propose a modification to the existing approach of measuring IC in the VAIC method.

Continuation of the paper henceforth is organised as follows. A review of past studies on methods of measuring IC, studies which adopted the VAIC method to measure IC, and studies that highlighted limitations of the method is conducted next. This is followed by an explanation of the methodological concerns of the study. Then 
empirical results of the analysis are presented, followed by the discussion and conclusion.

\section{Literature Review}

\section{Methods of Measuring IC}

Methods of measuring IC are still evolving (Tan et al., 2007) and a single most appropriate measure for IC has not been identified yet. There are two groups of researchers, namely, cost group and value group attempt to measure IC. Cost group captures the intellectual essence through the difference between market and book value of the firm. This group uses the market-to-book value ratio as an effective yardstick to value IC. The value group mainly uses the VAIC method.

Various methods have been applied to measure IC, and such measures include traditional financial measures (i.e. Tobin's q), recently developed non-financial performance measures (i.e. Balanced Scorecard) and the latest models (i.e. VAIC method) (Kamath, 2007). However, Komnenic and Pokrajcic (2012) state that none of the existing measures can fully meet the qualitative criteria or fulfil all the needs of users. In early 1990s, various frameworks were developed to measure the performance of a firm by overcoming weaknesses of financial measures that were used to measure performance of firms (Bourne, Mills, Wilcox, Neely, \& Platts, 2000). This initiation emerged because of the greater focus on intangible resources (Amir \& Lev, 1996). Although a few measures had been developed during the 1990s the lack of proper measures to measure IC can be observed even in the beginning of the $21^{\text {st }}$ century (Guthrie, Petty, \& Johanson, 2001). Furthermore, they have emphasised the necessity of developing new measures to measure IC for organisations where traditional accounting practices are not competent enough to identify and measure intangibles. Among the formulated methods, Intangible Assets Monitor (Dorweiler $\&$ Yakhou, 2005) and Skandia Navigator (Sveiby, 1997) were developed specifically for recognising the IC of firms (Tayles, Pike, \& Sofian, 2007). Even though the Balanced Scorecard (Kaplan \& Norton, 2004), another method of valuing IC, had been able to incorporate relational, structural and human capital perspectives with the financial perspective, it can be argued that the Balanced Scorecard has not been used to measure the IC of a firm singularly because it has more strategic focus. Moreover, Abeysekera (2003) and Dzinkowski (2000) have recommended using measures such as market-to-book value, intangible value and knowledge capital to assess IC. Similarly, Lev (2001) has emphasised that the Value Chain Scoreboard is a vital tool for managers and investors to measure the impact of intangibles on corporate 
performance and valuation. Tan et al. (2007) list out the available IC measures, including the afore-mentioned measures, as presented in Table 1.

Table 1: IC Measures

\begin{tabular}{|c|c|c|}
\hline $\begin{array}{l}\text { Key non-dollar valuation } \\
\text { of IC }\end{array}$ & $\begin{array}{l}\text { Key dollar valuation } \\
\text { of IC }\end{array}$ & $\begin{array}{l}\text { Other methods from } \\
\text { accounting bodies and } \\
\text { practitioners }\end{array}$ \\
\hline $\begin{array}{l}\text { - The Balanced Scorecard } \\
\text { - Technology Broker } \\
\text { Method } \\
\text { - Skandia IC Report } \\
\text { Method } \\
\text { - IC Index } \\
\text { - Intangible Asset Monitor } \\
\text { - Approach } \\
\text { - Heuristic Frame } \\
\text { - Eital Sign Scorecard } \\
\text { - Ernst and Young Model }\end{array}$ & $\begin{array}{l}\text { - } \text { EVA and MVA Model } \\
\text { - Market-to-book Value } \\
\text { Model } \\
\text { - Tobin's q Method } \\
\text { - Pulic's VAIC }{ }^{\mathrm{TM}} \text { Model } \\
\text { - Calculated Intangible } \\
\text { Value } \\
\text { - Knowledge Capital } \\
\text { Earnings Model }\end{array}$ & $\begin{array}{l}\text { - Human Resource Costing } \\
\text { and Accounting } \\
\text { - Accounting for Future } \\
\text { - Total Value Creation } \\
\text { - The Value Explorer } \\
\text { TM } \\
\text { and Weightless Weights }\end{array}$ \\
\hline
\end{tabular}

Source: Tan et al. (2007)

Diversity in inherent merits of each IC measure ensures their survival and their demerits however create cautions for researchers in selecting a suitable measure for their studies. In reviewing the three categories in Table 1, the major criticism against non-dollar measures is that the data used to calculate those measures are subjective to the necessities of the firm and mostly unavailable in audited financial statements (Roos, Roos, Dragonetti \& Edvinsson, 1997). Lack of standardisation could be a probable challenge for non-dollar measures, especially, in respect to statutory reporting (Andriessen, 2004; Bontis, 2001). Consequently, according to Firer and Williams (2003), the above-specified limitation of non-dollar measures restricts the comparison of results among other firms. Furthermore, the lack of awareness on the contextual differences when developing measures and the questions related to the external validity of a study, which adopts an existing IC measure can also be cited as criticisms against the available IC measures. The remainder of this section details out ten quantitative IC measures.

\section{Market-to-book Value Method/Market or Value Based Approach (MBM)}

This approach is the simplest way of calculating IC. Further, the $M B M$ could be identified as the most frequently used IC measure (Dzinkowski, 2000). According to Housel and Nelson (2005) the MBM captures the difference between stock market value of the firm and the net value of its assets. Stock market value is the market price per share multiplied by number of issued shares. Book value is the net value of firm's 
assets (net of depreciation). However, it is unclear whether opening balance sheet values, closing balance sheet values or average values should be used in applying this method to compute IC. According to Dzinkowski (2000), the main advantages of this measure are that it is easy to calculate and can be compared with other measures. It is directly related to the widely used operational definition for IC that IC is the difference between market-value and book-value (Goebel, 2015; Tseng, Lin, \& Yen, 2015). However, Dumay (2012) and Housel and Nelson (2005) have identified the following inherited limitations of the method:

- share price is determined not only by tangible and intangible assets of the firm, and many other external factors can influence it;

- book value is the net of depreciation and it does not represent the revenue generation amount;

- many of the tangible assets recorded on the balance sheet are much lower than their current market value;

- it measures IC as a whole and does not measure IC components or elements;

- the current financial accounting model does not attempt to value a firm in its entirety though the market values a firm in its entirety;

- difference between market and book value of the firm cannot entirely be attributed to IC due to anomalies in historical cost accounting for assets; and

- continual fluctuation of share prices distorts the value of IC.

\section{Knowledge Capital Earnings Method/Residual Income Method (KCE Method)}

Lev (2001) and Wall, Kirk, and Martin (2004) have elaborated that KCE method involves the following steps to compute knowledge capital earnings:

Step 1: Find the average annual earnings of a company. It suggests using three years of actual earnings, and three years of forecasted earnings by the financial analysts to compute normalised earnings.

Step 2: Identify financial assets reported on the balance sheet and then compute the expected after tax return on financial assets.

Step 3: Turn to physical assets and take average after tax return for physical assets.

Step 4: Take the total of return on financial assets and the return of physical assets to be deducted from normalised earnings to find out knowledge capital earnings.

Step 5: Knowledge capital earnings should be deducted from the expected rate of return on knowledge assets. Expected rate of return on knowledge assets (intellectual asset discount rate) is determined by taking the correlation between IC earnings and equity returns. 
According to Housel and Nelson (2005) and Wall et al. (2004), the main advantage of this method is the use of both earnings and assets to compute IC rather than totally relying on assets. However, the same authors have identified certain limitations of the method such as choice of expected return on assets being somewhat arbitrary, the model not identifying the value derived from individual components of IC, and the uncertainty whether IC can be valued merely as residual assets because Resource-based View shows that IC is embedded in competitive advantages.

\section{Economic Value Addition (EVA) and Market Value Addition (MVA) Methods}

Bontis (2001) has mentioned that EVA concentrates on maximising incremental earnings over capital costs. MVA represents the spread between the cash that firm's investors have to put into the business since the establishment of the company and the present value of the cash that they can earn by selling their shares (Bontis, 2001). In another way, the difference between the firm's total value and the total capital that the investors have invested in is called the MVA. Further, EVA is intended to offer improvements to the market value added calculation and EVA can be used as a surrogate measure for the stock of IC assuming that the effective management of knowledge assets increases EVA (Bontis, 2001). The computation of EVA can be summarised under two options:

Option 1: $E V A=$ Net sales - operating expenses - taxes - capital charges

Capital charges $=$ Weighted average cost of capital $(W A C C) \times$ Total capital invested

Option 2: $E V A=$ Profit after tax $(P A T)-W A C C \times$ Total capital invested

where, $W A C C=$ Cost of debts $\left(k_{d}\right)+$ Cost of equity capital $\left(k_{e}\right)$

$k_{d}=$ Interest $\mathrm{x}(1-t) /$ Total debts

$k_{e}=R_{f}+\beta\left(R_{m}-R_{f}\right)$

$R_{f}=$ Risk free rate (10-year treasury bill rate is used in the present study)

$R_{m}=$ Expected market return

$\beta=$ Market risk

$t=$ Tax rate

Total capital invested $=$ Share capital + Debt capital

As advantages Bontis (2001) has stated that EVA method has received widespread acceptance among the financial community. Further, the author has mentioned that MVA can represent the market assessment of the net present value of a company's 
current and contemplated capital investment projects. As such, MVA is a significant summary assessment of corporate performance. According to Bontis (2001), MVA is gains and losses accruing from historic activities when aggregated on a one-to-one basis with last year's results plus today's moods as they are shown in the marketplace. Moreover, Bontis (2001) has identified three limitations of EVA. They are; the use of book assets relies on historical costs in which current market or replacement value is not represented, empirical research has not conclusively shown that EVA is a better predictor of stock price or its variation, and the starting point for EVA analysis assumes that companies should be run in the interest of shareholders exclusively.

\section{Calculated Intangible Value (CIV)}

This approach computes the fair market value of intangible assets. In other words, the method calculates the excess return on hard assets. Briefly, the method uses a three-year period for averaging the pre-tax earnings and tangible assets to calculate company's return on assets, which is then compared with the industry average (Abeysekera, 2007). The CIV involves the following detailed process in computing intangible values:

- Calculate average pre-tax earnings for the past three years.

- Take the average year-end tangible assets for the same three years.

- Divide earnings by assets to compute return on assets $(R O A)$.

- Find industry average ROA.

- Compute excess return using the equation: Excess return = (Industry average $R O A \times$ average company tangible assets) - pre-tax earnings.

- Find the three-year average income by multiplying excess return by tax-rate.

- Determine IC as the present value of the premium above. Present value percentage is the cost of capital of the company.

This method is based on the assumption that a company's premium earnings (when earnings are greater than those of an average company within the industry) are a result of IC in the company. This further implies that a company can reach only an average level of earnings by utilising tangible assets and that IC generates the premium. The CIV facilitates inter-company and industry comparisons. The method also uses data on financial statements to ensure the reliability and consistency of intercompany and industry comparisons. However, Abeysekera (2003) argues that the usage of average but not the actual return on assets to determine excess return on assets, and company's cost of capital dictates the net present value of intangible assets. In addition to the above limitation, the fact that average $R O A$ is susceptible to 
outlier effects, the inability to evaluate individual elements of IC and the question of how IC can be separated from goodwill remained as disadvantages of CIV.

\section{Tobin's q Ratio}

Tobin's q ratio is another proxy measure to assess IC. According to Dzinkowski (2000), Tobin's q is one of the most suitable methods to assess the relevance of IC of firms within the same industry and is computed over a period of several years. Usually, the replacement cost is necessary to compute the Tobin's q. Tobin's q accounts for both past and expected future performances of the firm (Hejazi, Ghanbari, \& Alipour, 2016). However, the difficulty of estimating the information needed to calculate the Tobin's q stands as the main limitation (Ghosh \& Wu, 2007). The ratio identifies the difference between the market value of the firm and the replacement cost of its tangible assets. A widely used proxy for the $q$ ratio is the excess of market value of a firm over the accounting book value of its tangible assets. According to Chung and Pruitt (1994) and Housel and Nelson (2005), the $q$ ratio is calculated as follows:

$$
\begin{aligned}
& \text { Tobin's } q \\
& =\frac{[(M V \text { of } C S)+(B V \text { of } P S)+(B V \text { of } S T L)+(B V \text { of } L T L)-(B V \text { of STA })]}{B V \text { of } T A}
\end{aligned}
$$

where, $M V$ is market value, $C S$ is common stock, $B V$ is book value, $P S$ is preferred stock, STL is short-term liabilities, LTL is long-term liabilities, STA is short-term assets and $T A$ is total assets. Although the $q$ ratio assists IC practitioners to assess the IC of firms, the usage of this method is limited because it was developed in the industrial era. Therefore, its applicability in the knowledge economy is questionable as the former economy placed more importance on physical assets and the latter has both physical and knowledge assets (Abeysekera, 2003). Apart from the difficulty of estimating the replacement cost of intangible assets, in practice, this model suffers from the inability to value the individual components of IC separately.

\section{Return on Assets Method (ROA Method)}

According to Rodov and Leliaert (2002), the ROA of a particular firm is calculated using the following equation:

$$
R O A=\frac{\text { Average earnings of a company over three to five years }}{\text { Average tangible assets over the same period }}
$$


Then, $R O A$ of the firm is compared with the industry average to identify the difference. If the ratio is zero or negative, the company is considered as not having excess IC. If it is positive, the excess is multiplied by the company's average tangible assets to calculate the average annual excess earnings. Eventually, the excess earning of the firm is divided by the average cost of capital to estimate the value of IC.

\section{Market Capitalisation Method (MCM)}

$M C M$ recognises IC as the excess of a company's market capitalisation over its stockholders' equity (Chan, 2009). The MCM is based on the capital market premium and share price quotations. In order to calculate $M C M$ accurately, historical financial statements must be adjusted to reflect the effects of inflation or replacement costs (Wall et al., 2004). One limitation of this approach is that it does not easily assist managers to get a comprehensive understanding of the IC (Andriessen, 2004; Bontis, 2001; Guthrie et al., 2001).

\section{Knowledge Capital Valuation Method (KC Method)}

According to Wall et al. (2004), KC method uses economic profits (financial capital rental) as a basis to compute knowledge capital. Then, the method identifies the difference between profits and financial capital rental before dividing it by the interest of long-term debts.

\section{Intellectual Capital Formula}

El-Tawy and Tollington (2010) have adopted this formula to compute IC. The following formula is used to calculate the intellectual assets $(I A)$ of a firm:

$$
I A=\sum_{i=0}^{n} X(1-r)^{i} * C F
$$

where, $X$ is first year sale, $n$ is expected life of the product (in years or months), $r$ is a suitable discount rate, $C F$ is the contribution proportion that the new idea had in terms of the ultimate success of the product (a number between $1-0$ ). A major limitation of this technique could be the subjective nature of the estimates of $r, n$ and $C F$ values.

\section{Discounted Residual Income Approach (DRI)}

As long as earnings and book value of the firm are forecasted in a manner consistent with clean surplus accounting, the value of a rational firm can be measured by the sum of firm's book value and the present value of the expected future residual 
income (Ohlson, 1995). Frankel and Lee (1998) have restated the above argument as added infinite sum of discounted residual income to the reported book value as follows:

$$
\begin{aligned}
& F V_{t}=B V_{t}+\sum_{i=1}^{\infty} E_{t}\left[N I_{t+1}-\left(R_{e} B V_{t+i-1}\right)\right] /\left(1+R_{e}\right)^{i} \\
& F V_{t}=B V_{t}+\sum_{i=1}^{\infty} E_{t}\left[\left(R O E_{t+1}-R_{e}\right) B V_{t+i-1}\right] /\left(1+R_{e}\right)^{i}
\end{aligned}
$$

where, $F V_{t}=$ present value at time $\mathrm{t} ; B V_{t}=$ book value at time $\mathrm{t}$; $E_{t}=$ expected future residual income; $N I_{t+1}=$ net income for period; $R_{e}=$ cost of equity capital; $B V_{t+i-1}$ $=$ book value at $t+\mathrm{i}-1$; and $R O E_{t+1}=$ after tax return on book equity for period $t+1$.

The above model is used to measure the present value of the future discounted cash flows, which are not captured in the current book value and $R_{e}$ is against financial theory (Tsai \& Hua, 2006). Therefore, Tsai and Hua (2006) replaced WACC in the place of $R_{e}$ and adopted the following model to measure IC:

$$
I C_{t}=\sum_{i=1}^{\infty} \frac{E_{t}\left[\left(R O E_{t+1}-R_{e}\right) B V_{t+i-1}\right] /\left(1+R_{e}\right)^{i}}{(1+W A C C)^{i}} \times\left[\frac{1}{2}\left(B V_{t-1}+B V_{t}\right)\right]
$$

Finally, $I C_{t}=\frac{\left(R O E-R_{e}\right)}{W A C C} \times\left[\frac{1}{2}\left(B V_{t-1}+B V_{t}\right)\right]$

where, $I C_{t}=$ firm's IC; $R O E=$ weighted average after tax return on book value of equity in last five years (previous five quarters in this study) on the weights of 1,2,3,4, and 5 from first year to last year (first to last quarter in this study); $R_{e}=$ Cost of capital based on the capital assets pricing model $(C A P M) ; W A C C=$ weighted average cost of capital; $B V_{t}=$ book value at time $t$; and $B V_{t-1}=$ book value at time $t-1$.

Further, $W A C C=W_{d} \times R_{d}(1-\mathrm{t})+W_{e} \times R_{e}$; where $W_{d}$ is debt capital to total capital ratio, $R_{d}$ is interest rate, $\mathrm{t}$ is tax rate, $W_{e}$ is equity capital to total capital ratio, and $R_{e}=R_{f}+\beta\left(R_{m}-R_{f}\right)$. 
In addition to the discussed approaches to measure IC thus far, several researchers have adopted some other proxy measures to compute IC. For example, RiahiBelkaoui (2003) has used both trademarks and/or patents as a proxy measure for IC. Riahi-Belkaoui has initially taken the number of applications for trademark protection in each sample firm for ten years. Then the difference between the total trademarks of the sample firms and the median number of trademarks of the total sample was taken to represent IC. Additionally, Al-Twaijry (2009) has selected investments on intangible assets as a proxy variable for IC.

\section{VAIC Method}

Ante Pulic at The Austrian Intellectual Capital Research Centre first developed the VAIC method with the intention of measuring IC of firms. The method is known as a "universal indicator that shows abilities of a company in value creation, and it represents as a measure for business efficiency in the knowledge-based economy" (Pulic, 1998b, p. 9). Among the available IC measures, the VAIC method is being used widely in business and academic applications (Chan, 2009; Chen et al., 2005; Firer \& Williams, 2003; Pulic, 1998a, 2000a; Shiu, 2006). According to Kujansivu and Lonnqvist (2007), the method is based on the assumption of measuring and developing the value addition of a company. Tan et al. (2007) explain that the VAIC method was designed to provide value creation information on both tangible and intangible assets. Furthermore, the VAIC method measures the performance of IC and physical assets of the firm (Mavridis, 2005). Hence, this method facilitates computing and comparing the level of efficiency of IC and physical capital among firms. Majority of research work that was conducted with the purpose of establishing the relationship between IC and firm performance has frequently adopted the VAIC method to compute IC. According to Zeghal and Maaloul (2010), the VAIC method is still in the early stages of its application in management accounting practices and it needs to be empirically validated with a large number of companies. However, many researchers (such as Chan, 2009; Chen et al., 2005; Kamath, 2007, 2008, 2015; Kujansivu \& Lonnqvist, 2007; Tan et al., 2007; Shiu, 2006; Yalama \& Coskun, 2007; Gangi, Salerno, Meles, \& Daniele, 2019) identify the method as the most attractive among the available measures for IC. In addition, Chan (2009) recognises it as the most appropriate method to value IC.

As Kamath (2007) has identified, the logic for using the VAIC method as a tool to measure IC performance is supported by the following reasons:

- intellectual potential is the most important resource of corporate success, especially in the knowledge economy; 
- $\quad$ raising the efficiency of intellectual potential is the simplest, cheapest and most secure way to ensure sustainable business success;

- $\quad$ VAIC method has proved its suitability as a tool for measuring IC; and

- when companies have higher expenditure for intellectual potential than for physical capital, the VAIC method stands as a reliable indicator for intellectual potential.

Furthermore, this method has been used in studies on IC which were conducted in Malaysia, Singapore, United Kingdom, Greece, Turkey, Japan, India, South Africa, Australia etc. According to Tan et al. (2007), Pulic's VAIC method offers the advantages of easy acquisition of data to compute IC and enables further analysis on other data sources. Furthermore, Tan et al. (2007) state that the data needed to calculate the VAIC can be derived in the form of various ratios, which are calculated using standard financial numbers available in audited financial reports. According to Firer and Williams (2003) and Roos et al. (1997), the advantages of other alternative IC measures compared to the VAIC method, especially the measures which use nonfinancial information are different from its main advantage (easy acquisition of data) as mentioned above. Moreover, non-financial information is unique to a firm, customised to fit the profile of the firm, and information of one firm may not readily be available in other firms. Therefore, the VAIC method can be considered as a proper measurement for comparing the IC performance among firms. Further, Pulic (2001) has criticised the other IC measures, as they are inadequate in terms of comparability and scope.

Counter arguments for the above criticism have not been developed so far in the IC literature. According to Andriessen (2004), the VAIC method has been defined as a better indicator for statistical analysis because it simplifies the process and enables cross-sectional comparisons (Schneider, 1998 as cited in Nazari \& Herremans, 2007,) and it is objective and verifiable (Firer \& Williams, 2003). Sveiby (2010) has commented that the VAIC method is useful to illustrate the financial value of intangible assets, and the values can be compared with other companies in the same sector. Moreover, Firer and Williams (2003) have identified a number of advantages of the VAIC method: it is practically easy to use; it is a standardised and consistent measure that enables effective comparative analyses across firms and countries; and it has the potential for practical application in the analysis of information from financial reports of firms. Furthermore, Pulic (2001) has also stated that the VAIC method is an accepted, consistent and standardised method to measure and compare 
IC performance of the firm. Pulic (2001, 2002b) has emphasised that VAIC method enables internal (over a period for the same firm) as well as external comparisons (across sectors and countries).

Moving further in identifying the merits of the method, Mavridis (2005) has recognised it as a simple but excellent method of highlighting the intellectual phenomenon in a rational way, and as providing meaningful in-depth performance insights into the role of the physical capital and the human capital. Nazari and Herremans (2007) argue that qualitative methods to compute IC are attempting to measure IC within companies by referring to the indicators that are not publicly available. The alternative methods for the VAIC method have not developed mechanisms to deal with the issues of calculating market-based IC for companies that are not listed on the stock market and such methods have failed to explore the efficiency of human capital (Tan et al., 2007). Overall, the following advantages can be identified through the review of literature (mainly, Appuhami, 2007; Chang \& Hsieh, 2011; Chen et al., 2005; Firer \& Williams, 2003; Goh, 2005; Mavridis, 2004; Tseng \& Goo, 2005) which adopted the VAIC method for measuring IC:

- it generates objective, quantifiable and quantitative measurements without using subjective grading;

- its' indicators are useful and appropriate for all stakeholders who may want to identify and compare IC whereas most of the alternative measures are categorically informative for the shareholders;

- it exists as a ratio measurement drawn from the input of financial data, therefore, it is most suitable to be used along with traditional financial indicators of the business;

- it offers a relatively simple and straightforward process to compute the value creation efficiencies of assets. As a result, whoever who is familiarised with traditional accounting information may understand and apply the VAIC method;

- it can be used as a benchmarking method because it is a standardised measure which can be useful for internal (over a period of time for the same firm) and external (across sectors and countries) comparisons;

- the data needed to compute the VAIC are publicly and mostly freely available in the published financial statements. The reliability of the measure is also ensured as it uses data from audited financial statements;

- the VAIC approach is consistent with stakeholder view and the Resourcebased View as it uses a value added approach; 
- one of the main assumptions of the method is that human capital is the most important aspect of IC, which is consistent with all major definitions for IC; and

- the literature on IC measurement and testing of the relationship between IC and corporate performance shows that the VAIC method is the most widely used and the most popular among IC scholars.

According to Pulic (1998a, 2001, 2002a, b), the basic VAIC method can be explained as follows. Further, the present study refers to it as Method 1 among varied VAIC applications identified in this review.

\begin{tabular}{|c|c|c|}
\hline Output & $=$ & Gross income \\
\hline Input & $=$ & Operating expenses (excluding personnel costs) \\
\hline $\begin{array}{l}\text { Value Addition } \\
(V A 1)\end{array}$ & $=$ & Output (sales) - Input (brought-in-materials) \\
\hline$H C_{1}$ & $=$ & $\begin{array}{l}\text { Personnel costs (wages and salaries + retirement } \\
\text { benefits }+ \text { training and development expenses }+ \\
\text { other perquisites) }\end{array}$ \\
\hline $\begin{array}{l}\text { Capital Employed } \\
\left(C E_{1}\right)\end{array}$ & $=$ & $\begin{array}{l}\text { Physical capital (gross fixed assets - accumulated } \\
\text { depreciations) + Financial capital (total assets - } \\
\text { [physical capital + intangible assets]) }\end{array}$ \\
\hline$S C_{1}$ & $=$ & $V A_{1}-H C_{1}($ proxy for Structural Capital) \\
\hline$H C E_{1}$ & $=$ & $V A_{1} / H C_{1}$ (indicator for Human Capital Efficiency) \\
\hline$S C E_{1}$ & $=$ & $\begin{array}{l}S C_{1} / V A_{1} \text { (indicator for Structural Capital } \\
\text { Efficiency) }\end{array}$ \\
\hline$C E E_{1}$ & $=$ & $\begin{array}{l}V A_{1} / C E_{1} \text { (indicator for Capital Employed } \\
\text { Efficiency) }\end{array}$ \\
\hline $\operatorname{VAIN}_{1}$ & $=$ & $H C E_{1}+S C E_{1}$ (indicator for intellectual capital) \\
\hline VAIC $_{1}$ & $=$ & $\begin{array}{l}H C E_{1}+S C E_{1}+C E E_{1}(\text { Value Added Intellectual } \\
\text { Coefficient })\end{array}$ \\
\hline
\end{tabular}

Arguably, the Pulic's method of VAIC recognises VA based on the stewardship theory $(V A=$ gross income - operating expenses + personnel costs $)$ by including only the value adding sources for shareholders and employees of the firm. According to the stewardship theory, the major stakeholders of a firm are owners and employees (principals and stewards), and the intention of both groups is to work towards 
satisfying their own psychological and sociological characteristics (Davis, Schoorman, \& Donaldson, 1997).

Additionally, the VAIC method is based on several assumptions. Among them, the approach of calculating $V A$ is foremost. According to the method, VA is computed as the difference between sales and brought-in-materials. Explaining it further, output of a firm comprises the total revenue generated through selling products and providing services to the market, and input is identified as all expenses incurred in earning the revenue. However, the VAIC method does not recognise labour expenses as input but considered as an investment in the human capital of the firm. The VAIC method also assumes that labour (human capital) is a separate value creating entity of a firm and hence labour plays an active role in the value creation process. According to Mavridis (2005), the value addition of IC in a firm is represented in relation to two dimensions; namely human capital $(H C)$ and structural capital $(S C)$. Further, the method recognises the value creation efficiency of the capital employed in the firm. Pulic (2000a, b) argues that the capital employed and IC create the market value of a firm, where, IC consists of $H C$ and SC. The value creation efficiency of capital employed $(C E E)$, which is also referred to as physical capital efficiency is defined as:

$$
C E E=V A / C E
$$

The definition of $C E E$ presents that if one company has a higher $C E E$ than another does, the former company is better at utilising its physical assets. Thus, the VAIC method further assumes that better utilisation of $C E$ is a part of IC of a firm.

Apart from the $C E E$, the VAIC method identifies the human capital efficiency $(H C E)$ as well. The $H C E$ explains the value creation of one monetary unit spent on employees. Further, the VAIC method identifies $H C E$ as an indicator of the quality of human resources of the company. In computing the $H C$, total personnel cost is considered as the indicator. The $H C E$ is calculated as follows:

$$
H C E=V A / H C
$$

In addition to the two efficiencies identified above, structural capital efficiency (SCE) is also computed through the VAIC method. Accordingly, SC $=V A-H C$. Pulic (1998a) argues that there is a proportionate inverse relationship between $H C$ and $S C$ in the value creation process. Further, the $S C E$ measures the amount of $S C$ needed to 
generate one monetary unit of $V A$, and it indicates how successful $S C$ is in the value creation process. The $S C E$ is computed as below:

$$
S C E=S C / V A
$$

The sum of $H C E$ and SCE measures IC efficiency of a firm:

$$
V A I N=H C E+S C E
$$

Eventually, the aggregate ratio, VAIC, is calculated as the sum of the three efficiencies mentioned above. The VAIC (total corporate intellectual ability) can be calculated using the following equation:

$$
V A I C=C E E+H C E+S C E
$$

Advancing from the basic VAIC method (Method 1), various scholars have attempted to customise variables of it by using alternative theoretical assumptions to the already accommodated assumptions. Consequently, the focus of this review now shifts towards highlighting such alternative assumptions appearing in the IC literature. Such a review is also useful to explore the varieties of VAIC applications available in the extant IC literature. Moreover, the review of past studies, which adopted the VAIC method to measure IC, reveals that there are inconsistencies among findings of relatively similar studies. Clarke et al. (2011) also state that prior studies in different contexts, which used the VAIC method have reported mixed results. The existing IC literature however attempts to explain this situation by pointing out the fact that contextual differences (socio, political and economic differences) of samples could have had a significant impact on the findings (i.e. Abeysekera, 2007; Marr et al., 2004). Nevertheless, the IC literature thus far has not suspected that inconsistent applications of the VAIC method could also be another factor for reporting mixed findings. Therefore, the present study attempts to highlight such inconsistent applications of the VAIC method and examine the effect of those applications on the associations between IC and corporate performance.

Firer and Williams (2003) were the first to adopt Pulic's basic VAIC method (Method 1) by incorporating few different perspectives to compute its variables. In this respect, variations such as the calculation of $V A$ based on the stakeholder theory, representation of wages and salaries as $H C$, and the selection of book value of net assets to represent $C E$ can be highlighted. Furthermore, this widely cited study in 
almost all internationally conducted studies that used the VAIC method provides a guideline to the present study to identify another variation of the VAIC application. The VAIC method adopted in Firer and Williams (2003) can be summarised as follows. Further, it refers as Method 2 in the present study.

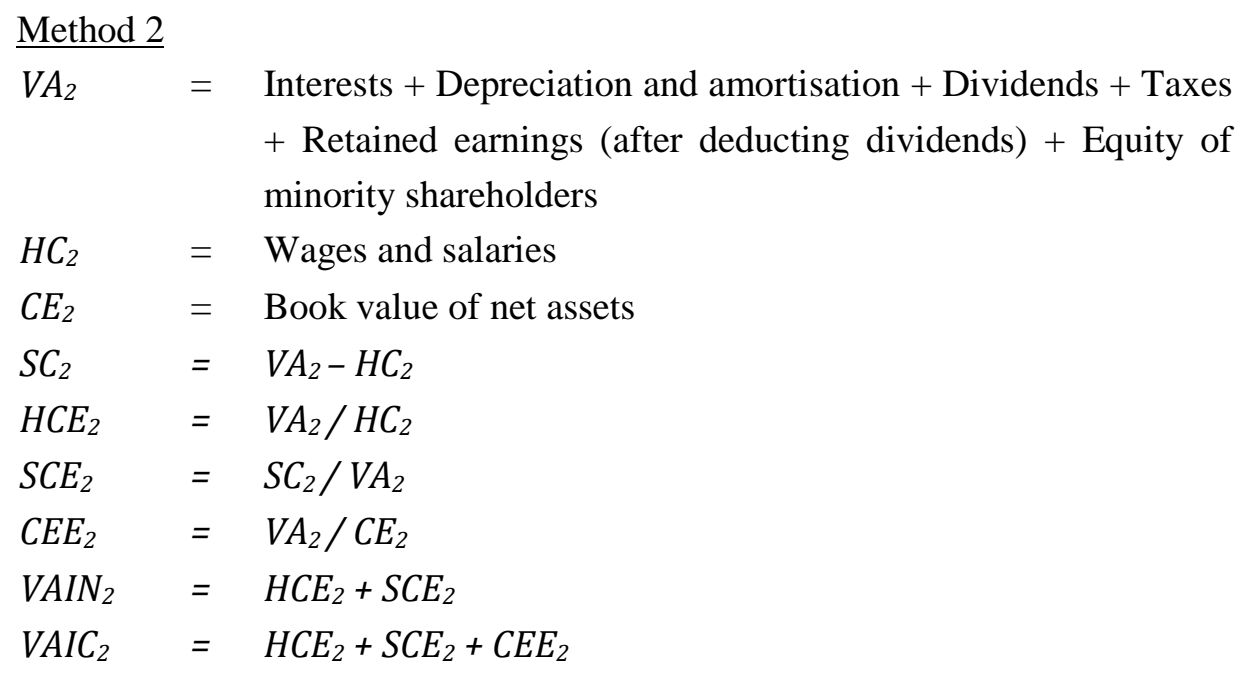

Yalama and Coskun (2007) have measured IC with a slight change to the Method 2 of VAIC stated above. The change made to the Method 2 in their study is the addition of wages and salaries to determine VA. Ahangar (2011) has used the VAIC method similar to Yalama and Coskun (2007). The approach to compute VAIC in Ahangar (2011) and Yalama and Coskun (2007) is referred as Method $2 a$ of VAIC:

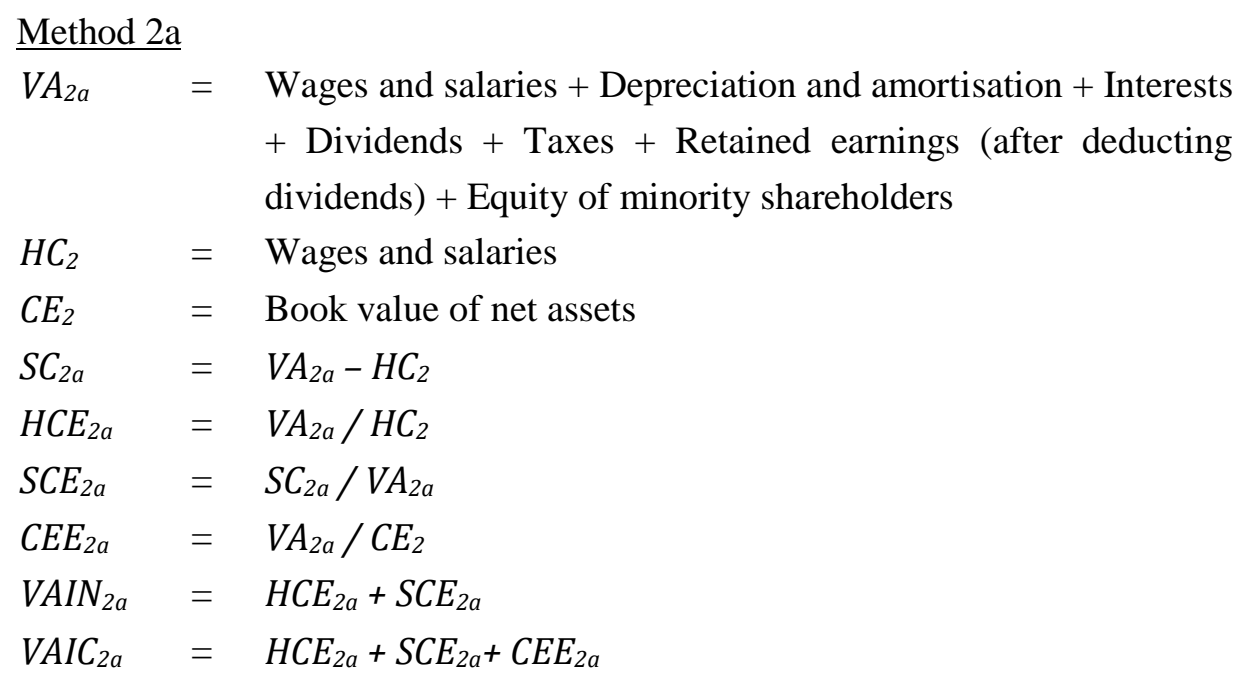


Calisir et al. (2010), Komnenic and Pokrajcic (2012) and Ting and Lean (2009) conducted studies that used the VAIC method with another different approach to compute VA compared to Methods 2 and $2 a$. Their approach to compute $V A$ is using Pulic's basic method (Method 1). Therefore, the present study identifies a Method $2 b$ to accommodate the said difference to Methods 2 and $2 a$. Method $2 b$ of VAIC is presented below:

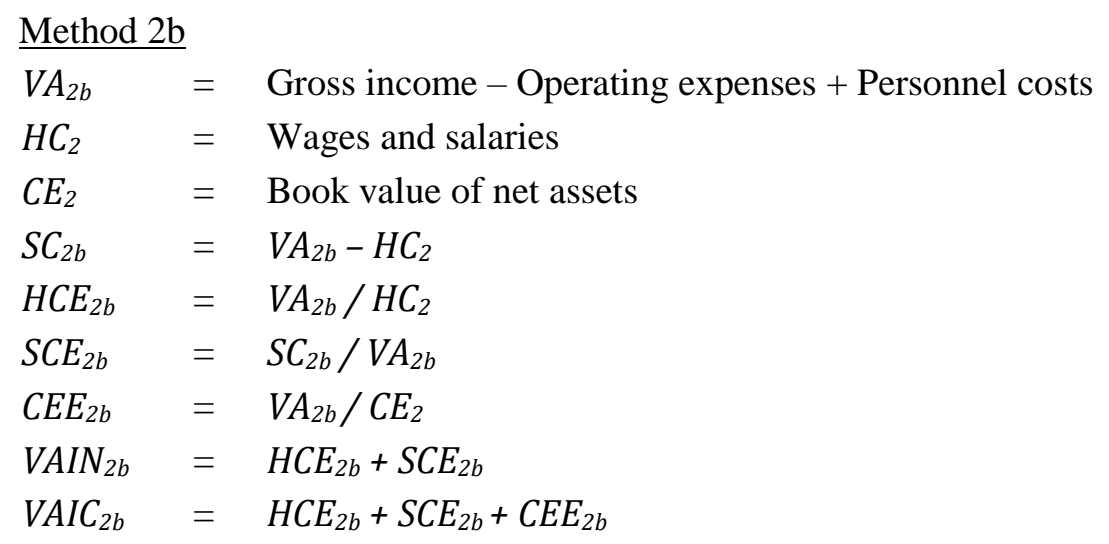

A well-manifested study was carried out by Chen et al. (2005) by largely adopting the basic VAIC method (Method 1) to measure the IC of firms selected for their study. However, they computed the $V A$ variable based on the stakeholder theory $(V A=$ Wages and salaries + Interests + Taxes + Retained earnings (after dividends) + Dividends + Depreciation and amortisation). This computation makes the VAIC method used in their study deviate from Pulic's standard method (Method 1). Hence, the present study identifies another approach for the VAIC method, Method 3, as presented below:

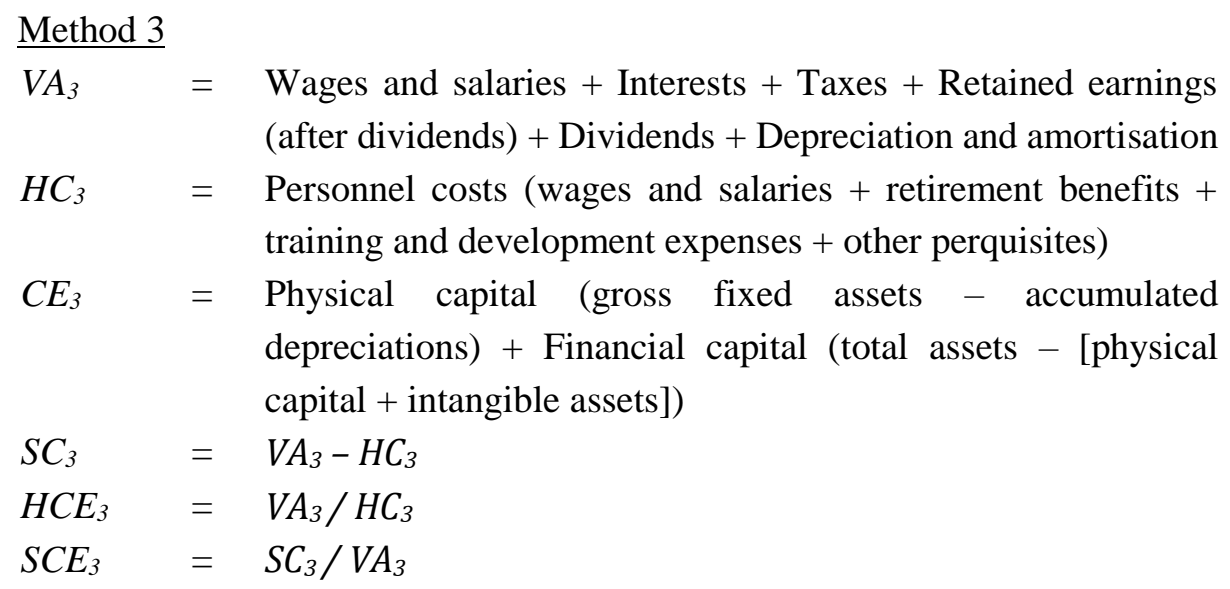




$$
\begin{array}{ll}
\mathrm{CEE}_{3} & =V A_{3} / C E_{3} \\
V_{\mathrm{VIN}} & =H C E_{3}+S C E_{3} \\
V A I C_{3} & =H C E_{3}+S C E_{3}+C E E_{3}
\end{array}
$$

Tan et al. (2007) measured IC of publicly listed companies on the Singapore Exchange. They used the Pulic's initial VAIC method (Method 1) to measure IC, but, with slight alterations. Those are, $\mathrm{HC}$ is represented by the aggregate value of wages and salaries, and capital employed was proxied by physical capital of the firm. Accomodating the above variations for the initial VAIC method in Tan et al. (2007), the current study identifies Method 4 of VAIC as elaborated below:



The application of the VAIC method in Clarke et al. (2011) to examine the effect of IC on firm performance of listed firms on the Australian Stock Exchange provides the platform to identify another varied application of the VAIC method. The identified variation is presented below as Method 5 of the VAIC.

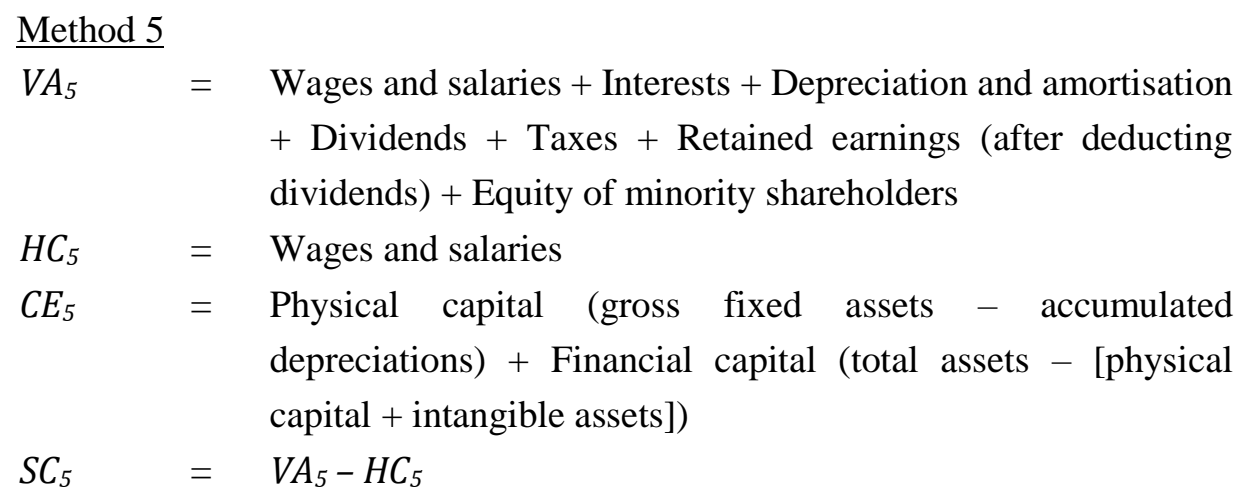




$$
\begin{array}{ll}
\mathrm{HCE}_{5} & =V A_{5} / H C_{5} \\
\mathrm{SCE}_{5} & =S C_{5} / V A_{5} \\
\mathrm{CEE}_{5} & =V A_{5} / C E_{5} \\
\text { VAIN }_{5} & =H C E_{5}+S C E_{5} \\
\text { VAIC }_{5} & =H C E_{5}+S C E_{5}+C E E_{5}
\end{array}
$$

According to Clarke et al. (2011), computation of $V A(V A=$ Wages and salaries + Interests + Depreciation and amortisation + Dividends + Taxes + Retained earnings (after deducting dividends) + Equity of minority shareholders) in Method 5 is based on the stakeholder theory. Further, they have identified $H C$ as the aggregation of wages and salaries. These are the two adjustments that Clarke et al. (2011) have made to the basic VAIC method (Method 1).

\section{Limitations and a Modification to the VAIC Method}

This sub-section recognises limitations of the VAIC method and rationalises the suggested modification to its existing procedure to compute IC. As far as the rigour and evolution of existing IC measures are concerned, Nazari and Herremans (2007) expressed that IC measures are still in the exploratory stage and researchers from different disciplines and viewpoints from different theories have an opportunity to add to the multidimensionality of existing IC measures. Similarly, Kamath (2007) has pointed out that existing parameters for evaluating IC performance are not exhaustive. Corresponding to these views, this study suggests a modification to the existing VAIC method by carefully analysing the fundamental assumptions of it. Additionally, the modification focuses on the practical usage of the method in a different perspective as discussed next.

There is a growing body of knowledge that point out demerits of the VAIC method despite the fact that it has gained some recognition as an efficient measure for IC. In the same vein, the present study identifies the inability of the VAIC method to decompose value creation efficiency of relational capital $(R C)$ as a key drawback. It is acceptable that IC scholars had initially recognised human capital $(H C)$ and structural capital (SC) as components of IC. For example, Bontis (2004), Edvinsson (1997) and Edvinsson and Malone (1997) decomposed IC into HC and SC during the relatively early stages of IC research. In this circumstance, the $R C$ was included in $S C$. However, the prominence of decomposing $R C$ and $S C$ into two separate components arises when external investors value each component differently in the context of contemporaneous agreement on IC components being around $H C, S C$ and $R C$ (i.e. 
Cabrita \& Bontis, 2008; Nazari \& Herremans, 2007; Tayles et al., 2007). The evolution of IC components shows an agreement on $H C, S C$ and $R C$ as components of IC. In this connection, failure to revise underlying assumptions of the VAIC method in reflection to the said epistemological changes essentially affects the efficiency of the method adversely. Stahle et al. (2011) also point out that the VAIC method does not deal with $R C$ at all. Meanwhile, the marketing literature highlights the importance of market intelligence in creating performance of the firm. Further, the present study recognises internally derived market intelligence of a firm as $R C$.

According to Cabrita and Bontis (2008), little research has focused on the importance of $R C$ and its association with corporate performance. To support this observation, Dawes (2000) found that competitor orientation, a component of market orientation, has emerged as a variable, which shows the strongest association with performance. Moreover, it can be argued that the inability to establish the association between $R C$ and corporate performance is partly accounted for the failure of computing the $R C$ component using existing IC measures. Alternative to establishing the direct relationship between $R C$ and firm performance, $R C$ can also be included as a control variable in regression models. In both options, sales and distribution expenses could be used as a proxy variable for $R C$. This is because according to Laing, Dunn, and Hughes-Lucas (2010), marketing expenditure is a proxy measure for $R C$. Furthermore, Gelb and Siegel (2000) have discovered that firms with larger amounts of research and development expenses and advertising expenditures have a positive impact on market reaction, which increases dividends and stock repurchase announcements.

Apart from the above-discussed issue related to distinguishing $R C$, Chu et al. (2011) have identified several other limitations of the VAIC method. Firstly, the method is inadequate to handle companies with a negative book value of equity or negative operating profits. Secondly, the inverse relationship between $H C$ and $S C$ is not immediately apparent in the method though it is theoretically sound and persistent with the general definition of IC. Thirdly, although the VAIC method depicts the value addition of human capital, structural capital and capital employed, it does not calculate the contribution of each element of different components of IC. This limitation eventually affects prioritising investments in IC elements to increase values of the IC components. Further, Andriessen (2004) mentioned that the VAIC method as well as other IC measures might not sufficiently identify the synergistic effects for value creation from interactions of different forms of capital. 
Kamath (2007) has identified three different ways to move ahead to develop a new method for measuring IC as stated below:

1. Adjusting conventional methods of accounting to accommodate new parameters and variables.

2. Retaining the traditional accounting methods and adding new measures to account for IC.

3. Abandoning old methods completely and creating a new method.

Following the second suggestion in Kamath (2007), the present study expects to add new measures to a widely used measure for IC. As highlighted previously, the VAIC method has been selected for this purpose.

The modification begins with the selection of input variables to the suggested VAIC method. First, a suitable approach to compute $V A$ has been selected. An observation on the available approaches in IC literature to compute VA for the VAIC method reveals that there are two theories behind its computation, namely, stewardship theory and stakeholder theory. The stewardship theory identifies the value adding components to owners and employees ( $V A=$ Gross income - Operating expenses + Personnel costs). This approach uses Pulic's basic method of VAIC (referred as Method 1 in the present study). The subsequent adoptions of the VAIC method use stakeholder theory to identify value additions of the firm. This approach considers the value adding sources for all stakeholder groups (i.e. owners, employees, financial institutes, government, etc.). Hence, the present modification computes the $V A$ of the firm based on the stakeholder theory since its $V A$ sources cover the entire groups of stakeholders without limiting to owners and employees as mentioned in the stewardship theory. $C E$ variable of the modification is computed as the aggregation of physical capital and financial capital. This approach is widely used in the IC literature compared to some of the VAIC applications (i.e. Method 2 and Method 4) that use physical capital only. Similarly, the $H C$ variable is represented by the total personnel costs of the firm. This inclusion is much more representative of what firms invest on employees rather than including wages and salaries as several past VAIC applications have done (i.e. Methods 2, 4 and 5). As discussed before, sales, marketing and advertising expenses is the proxy variable for $R C$ - the remaining input variable of the modified VAIC method.

In conclusion, the modified VAIC method can be elaborated as follows. Moreover, the modified method is referred to as Method 6 in this study. 


\section{$\underline{\text { Method } 6}$}

\begin{tabular}{|c|c|c|}
\hline$V A_{6}$ & $=$ & $\begin{array}{l}\text { Total staff costs }+ \text { interests }+ \text { depreciation and } \\
\text { amortisation }+ \text { dividends }+ \text { taxes }+ \text { retained earnings } \\
\text { (after deducting dividends) }+ \text { equity of minority } \\
\text { shareholders }\end{array}$ \\
\hline$C E_{6}$ & $=$ & $\begin{array}{l}\text { Physical capital (gross fixed assets - accumulated } \\
\text { depreciations) + financial capital (total assets - [physical } \\
\text { capital + intangible assets]) }\end{array}$ \\
\hline$H C_{6}$ & $=$ & $\begin{array}{l}\text { Personnel costs (wages and salaries }+ \text { retirement benefits } \\
+ \text { training and development expenses }+ \text { other perquisites) }\end{array}$ \\
\hline$R C$ & $=$ & Sales, marketing and advertising expenses \\
\hline$\left(S C_{6}+R C\right)$ & $=$ & $V A_{6}-H C_{6}$ \\
\hline$H C E_{6}$ & $=$ & $V A_{6} / H C_{6}$ \\
\hline$R C E$ & $=$ & $V A_{6} / R C$ \\
\hline$S C E_{6}$ & $=$ & {$\left[\left(V A_{6}-H C_{6}\right) / V A_{6}\right]-R C E$} \\
\hline$C E E_{6}$ & $=$ & $V A_{6} / C E_{6}$ \\
\hline $\operatorname{VAIN}_{6}$ & $=$ & $H C E_{6}+S C E_{6}+R C E$ \\
\hline VAIC $_{6}$ & $=$ & $C E E_{6}+H C E_{6}+S C E_{6}+R C E$ \\
\hline
\end{tabular}

\section{Methodology}

\section{Sample and Data}

Firer and Williams (2003), Kamath (2007) and Nassar (2018) documented that financial services firms emphasise more on IC resources. Furthermore, knowledgeintensive companies tend to dominate the finance sector in the knowledge economy era (Ting \& Lean, 2009). In addition to this, banking firms use huge amounts of human capital and customer capital (Kamath, 2007). Linda et al. (2017) recognise the banking sector as one of the sectors that intensively utilises IC assets. According to D'Hulster (2009) the US, Canada and Switzerland are three countries with large international banking systems. In line with this, the present study limits to the banking sector firms listed on the NYSE - the largest stock exchange in the world. All 249 banking sector firms listed in the NYSE by January 012012 were selected initially to represent the research site of the paper. However, data of some firms were omitted due to the unavailability of quarterly financial statements throughout the sample period as they did not maintain listing status for a bulk of the quarters in the sample period. Eventually 58 firms were excluded from the sample and 191 were retained. 
Data of selected firms was extracted from published quarterly financial statements available on the Bloomberg database. The authors' decided to use quarterly financial data from the first quarter of 2000 to second quarter of 2011 of the above sample where the sample period is distant from the time this study was conducted. Nevertheless, the decision to use the above data set would not dilute the contribution of the study due to two reasons. Firstly, the prime usage of the data set was to extract the differences in IC values (independent variable of the study) through diverse applications of the VAIC method to input in statistical analyses. Secondly, the authors do not intend to emphasise on a contemporaneous relationship between IC and firm performance of the sample. Hence, the time period and cross section of data for this nature of an investigation become irrelevant. Since the data set was long and wide, the range within the values in which the variables are positioned was very broad. Hence, the outliers of the data set were handled in the following manner. The authors decided beyond which the values are considered to be outliers and then replaced such values with the average value of a particular variable in a given quarter calculated by excluding the identified outliers.

\section{Regression Model}

Data collected for this study were analysed by employing the following regression Model 1 for panel data. According to IC theory, a firm can generate superior performance in a sustainable manner through the efficient utilisation of its IC resources. Further, the Resource-based View of the firm persists that resources of the firm is the main driving force behind firm performance. Under these theoretical expectations, this study expects positive coefficient signs for independent variables of the regression model.

$$
Y_{i t}=\beta_{01}+\beta_{11} V A I N_{i t}+\beta_{21} C E E_{i t}+\varepsilon_{i t}
$$

where $Y_{i t}$ is a common notation for $\triangle A T O, R O A, R O E$ and $\triangle M B$ of $i^{\text {th }}$ firm in $t^{\text {th }}$ quarter. $\beta_{01}$ is the constant of the model. Calculated VAIN values based on the six methods summarised in this study represent the proxy measure for IC. VAIC method measures both intellectual capital efficiency (VAIN) (efficiencies of human capital, structural capital and relational capital), and physical capital efficiency $(C E E)$. The total of VAIN and CEE forms VAIC $(V A I C=V A I N+C E E)$ (total value creating ability of the firm using both intangible and tangible assets) which is termed as Value Added Intellectual Coefficient. Therefore VAIN is used as the proxy measure for IC in model (1). 
According to Forte, Tucker, Matonti, and Nicolò (2017) investment in IC is increasingly important to firms seeking to achieve productivity and efficiency gains. Productivity, profitability and market valuation are used as dependent variables of the study. Revenue divided by total assets forms the assets turnover ratio (ATO), and it represents the productivity of the firm (Chu et al., 2011; Kamath, 2008; Pal \& Soriya, 2012). Profitability is measured through return on assets $(R O A)$ and return on equity $(R O E)$ ratios. $R O A$ reflects the effectiveness of utilising available assets in creating profits. The ratio of operating profits to total assets is used to calculate it (Chen et al., 2005; Pal \& Soriya, 2012; Bala, Raja, \& Dandgo, 2019). ROE represents the return generated on common stocks of shareholders, and it is recognised as an important financial indicator for owners of the firm (Chen et al., 2005; Pal \& Soriya, 2012; Kamath, 2015). The computation of $R O E$ is performed using the ratio of net income to average shareholder equity. Market valuation is the remaining dependent variable. Market-to-book value ratio $(M B)$ is used as the proxy measure for the market valuation (Ghosh \& Wu, 2007; Kamath, 2015). The $M B$ is the market value of common stocks divided by book value of common stocks, where, market value of common stock is the average stock price multiplied by the number of shares outstanding. Average shareholder equity represents the book value of common stocks. The absolute values of $R O A$ and $R O E$ are used in the regression models considering that these variables are stationary at levels, according to Unit-root test. However, the change in $A T O$ and $M B$ values between the present and immediate past quarter (first difference) is included to overcome the non-stationary nature of these variables as evident in the Unit-root test.

Capital employed efficiency (CEE) of the VAIC method measures the physical capital intensity of the firm. According to Komnenic and Pokrajcic (2012) and Maji and Goswami (2016), physical capital intensity of the firm influences the firm performance. Therefore, CEE computed in six VAIC methods represents the other independent variable of the regression model.

\section{Empirical Results}

\section{Descriptive Statistics}

Table 2, 3 and 4 summarise descriptive statistics related to the variables used in the study. More specifically, Table 2 provides descriptive statistics for input variables namely, value addition (VA), human capital $(H C)$, capital employed $(C E)$, and relational capital $(R C)$ of different VAIC methods. Table 3 presents descriptive 
statistics on output variables of the VAIC methods. Table 4 summarises descriptive statistics of performance indicators used for the dependent variable of the study. Figures $1 \mathrm{~A}$ to $1 \mathrm{C}$ and $2 \mathrm{~A}$ to $2 \mathrm{G}$ depict the behaviour of average values of value drivers and created values in each VAIC method, respectively. Apart from the behaviour of variables during the sample period, the Figures provide a graphical aid to compare the behaviour of input and output variables of all VAIC methods.

According to Table 2, the VA of all VAIC methods ranges between 20.13 and 49.58. VA in Methods $1,2 a$ and 4 bears the minimum value and VA in Method 6 has the maximum value. VA in Methods 2, 3 and 5 reported a mean of 46.71 and Method $2 b$ has a value of 35.93. Figure 1A confirms that $V A$ of Methods $1,2 a$ and 4 has the lowest average and Method 6 has the highest. Figure 1A reveals that VA of Methods 2, 3 and 5 is much closely positioned to Method 6 , and $2 b$ behaves roughly in the middle of lower and higher limits. A closer view on the underlying differences behind $V A$ approach in each method points out methods that adopted Pulic's initial approach to calculate $V A$ are reportedly ranked in the lower band of 20.13. In contrast, the approach used to compute $V A$ in the suggested modification (Method 6) has recorded the highest average for VA (value of 49.8). VA in Methods 2, 3 and 5 is slightly lower than that of Method 6. Reason for this behaviour is that the latter method considers total staff cost as a $V A$ source whereas the former methods include wages and salaries (the remaining $V A$ sources are similar in both occasions). Method $2 b$ which excludes staff cost as a source of $V A$, despite all other $V A$ sources of Methods 2, 3, 5 and 6 are being included, is positioned between higher and lower bands. Standard deviation, the average difference between observed values and the mean, for VA in all VAIC methods reveals that $V A$ in Method 6 has the least dispersion (2.73 times of mean) and Methods 1, $2 a$ and 4 has the highest (3.34 times of mean).

$H C$ variable in Table 2 is included in the VAIC methods using two distinctive applications. They are; total personnel cost in Methods 1, 3 and 6, and wages and salaries in the remaining methods. A mean difference of 2.87 for $H C$ can be observed in Table 2. The behaviour of average $H C$ over the sample period is portrayed in Figure 1B. The difference between two $H C$ applications has occurred as Methods 1, 3 and 6 add other sources of personnel expenses to wages and salary expenses, whereas, the remaining methods are solely based on wages and salaries. Degrees of dispersion (i.e. 2.37 and 2.32 times of mean) are reflected in the standard deviation of $H C$. Approximately identical skewness and kurtosis in both occasions confirm that the distribution of two $H C$ approaches is very much similar. 
Table 2: Descriptive Statistics for Value Drivers of VAIC Methods

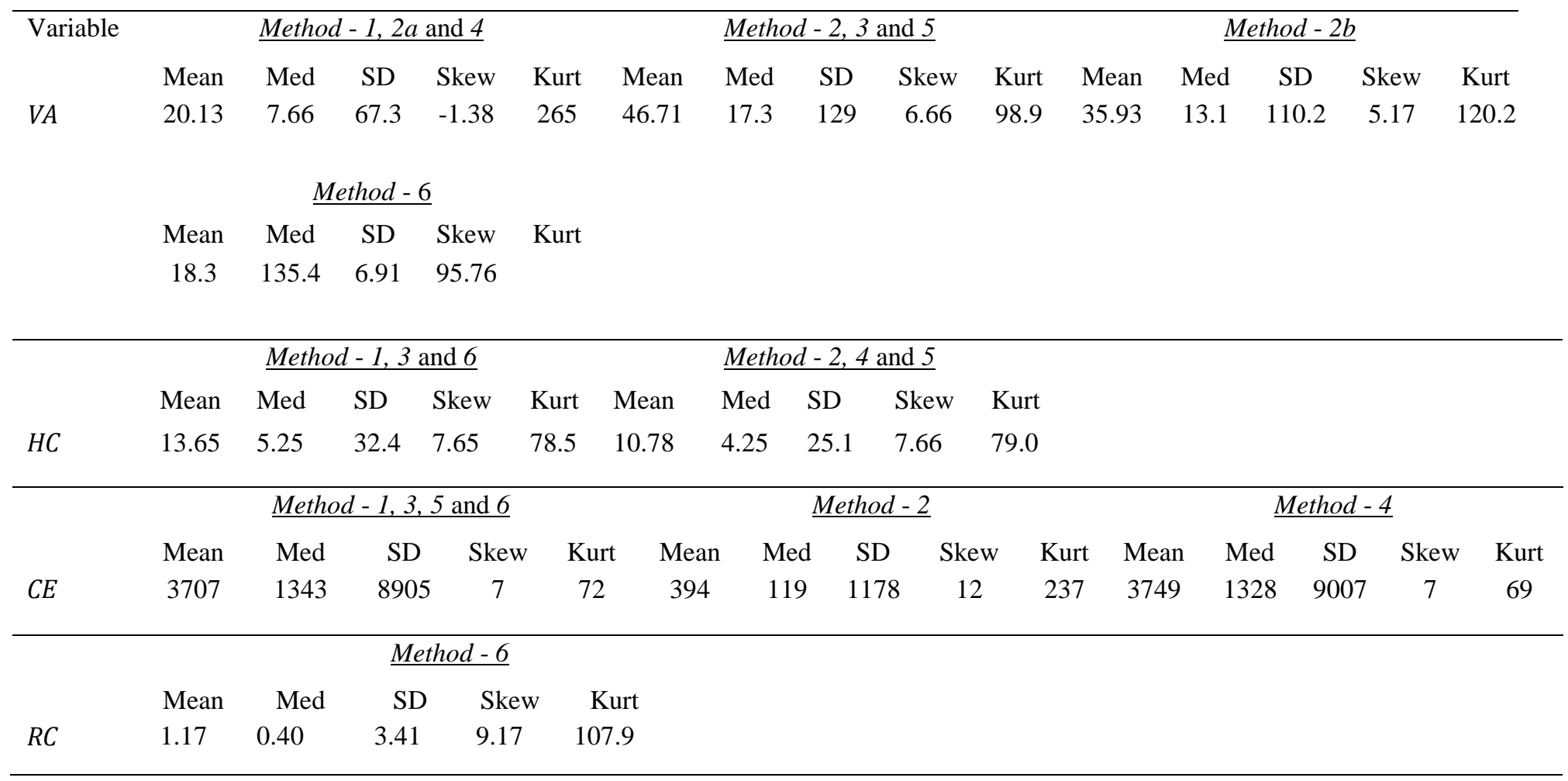


Table 3: Descriptive Statistics of Value Creators of VAIC Methods

\begin{tabular}{|c|c|c|c|c|c|c|c|c|c|c|c|c|}
\hline \multirow[t]{2}{*}{ Variable } & \multicolumn{2}{|c|}{ Method - 1} & \multicolumn{2}{|c|}{ Method -2 and 5} & \multicolumn{2}{|c|}{ Method $-2 a$ and 4} & \multicolumn{2}{|c|}{ Method - 2b } & \multicolumn{2}{|c|}{ Method - 3} & \multicolumn{2}{|c|}{ Method - 6} \\
\hline & Mean & Med & Mean & Med & Mean & Med & Mean & Med & Mean & Med & Mean & Med \\
\hline$S C$ & 6.48 & 2.69 & 35.93 & 13.01 & 9.34 & 3.61 & 25.14 & 8.61 & 33.04 & 11.93 & & \\
\hline$H C E$ & 1.53 & 1.62 & 4.64 & 4.38 & 1.90 & 2.01 & 3.64 & 3.38 & 3.73 & 3.52 & 3.92 & 3.72 \\
\hline$S C E$ & 0.47 & 0.39 & 0.73 & 0.77 & 0.57 & 0.51 & 0.71 & 0.71 & 0.67 & 0.72 & 0.57 & 0.71 \\
\hline$R C E$ & & & & & & & & & & & 0.038 & 0.019 \\
\hline \multirow[t]{3}{*}{ VAIN } & 2.01 & 2.02 & 5.38 & 5.18 & 2.48 & 2.52 & 4.36 & 4.10 & 4.40 & 4.25 & 4.53 & 4.46 \\
\hline & \multicolumn{2}{|c|}{ Method - 1} & \multicolumn{2}{|c|}{ Method - 2} & \multicolumn{2}{|c|}{ Method - $2 a$} & \multicolumn{2}{|c|}{ Method - 2b } & \multicolumn{2}{|c|}{ Method -3 and 5} & \multicolumn{2}{|c|}{ Method - 4} \\
\hline & Mean & Med & Mean & Med & Mean & Med & Mean & Med & Mean & Med & Mean & Med \\
\hline CEE & 0.005 & 0.006 & 0.14 & 0.15 & 0.06 & 0.07 & 0.11 & 0.11 & 0.013 & 0.014 & 0.006 & 0.006 \\
\hline
\end{tabular}

Method - 6

Mean Med

$0.014 \quad 0.015$

\begin{tabular}{|c|c|c|c|c|c|c|c|c|c|c|c|c|}
\hline \multirow[b]{3}{*}{ VAIC } & \multicolumn{2}{|c|}{ Method - 1} & \multicolumn{2}{|c|}{ Method - 2} & \multicolumn{2}{|c|}{ Method - $2 a$} & \multicolumn{2}{|c|}{ Method $-2 b$} & \multicolumn{2}{|c|}{ Method - 3} & \multicolumn{2}{|c|}{ Method - 4} \\
\hline & Mean & Med & Mean & Med & Mean & Med & Mean & Med & Mean & Med & Mean & Med \\
\hline & 2.01 & 2.02 & 6.12 & 5.94 & 2.54 & 2.59 & 4.47 & 4.23 & 4.42 & 4.26 & 2.49 & 2.53 \\
\hline & \multicolumn{2}{|c|}{ Method - 5} & \multicolumn{2}{|c|}{ Method-6 } & & & & & & & & \\
\hline & Mean & Med & Mean & Med & & & & & & & & \\
\hline & 5.39 & 5.18 & 4.55 & 4.47 & & & & & & & & \\
\hline
\end{tabular}




\section{Figure 1: Average Values of Input Variables of VAIC Methods}




Figure 2: Average Values of Value Creations through VAIC Methods

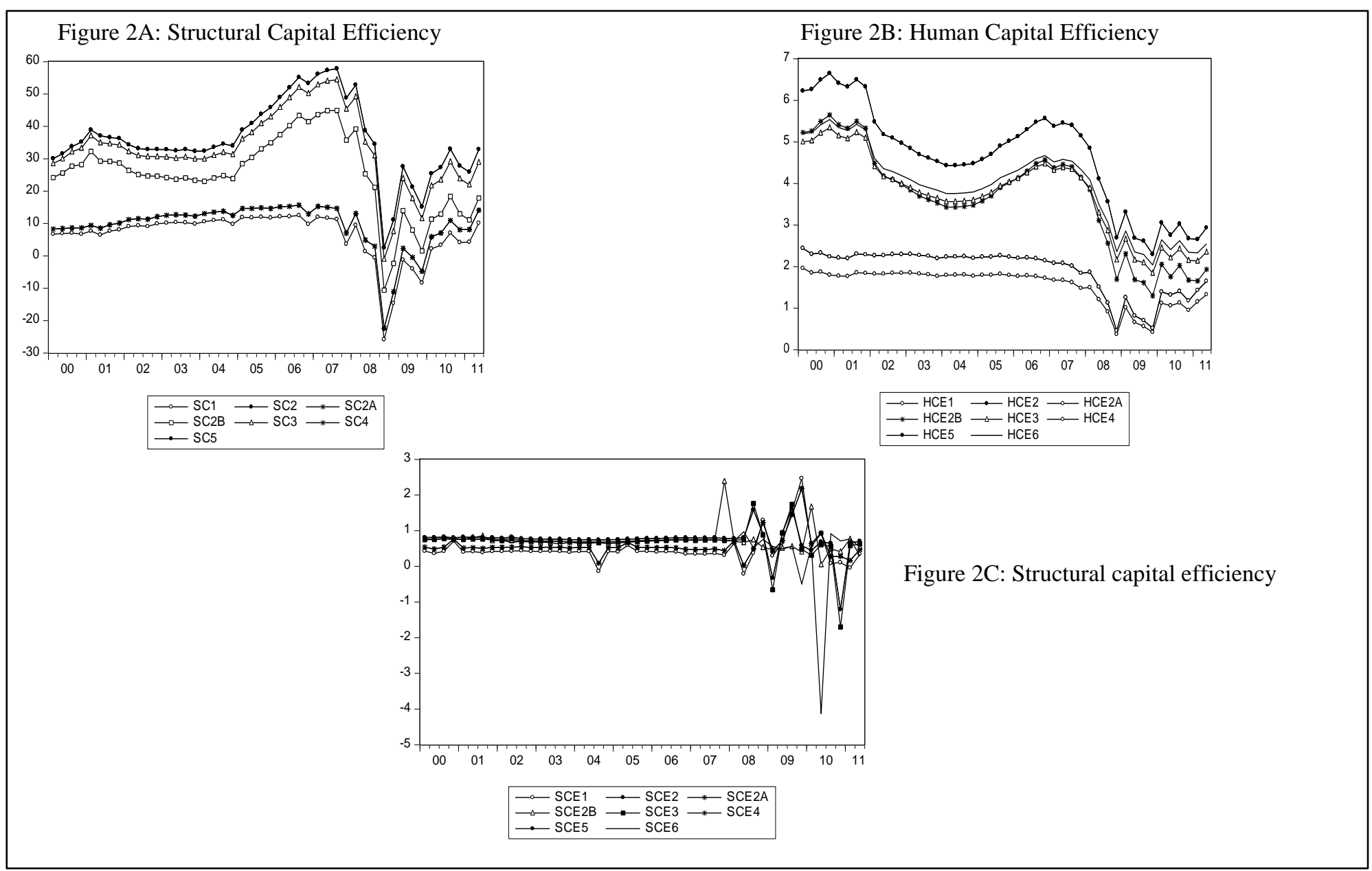


Figure 3: Average Values of Value Creations through VAIC Methods (Contd.)

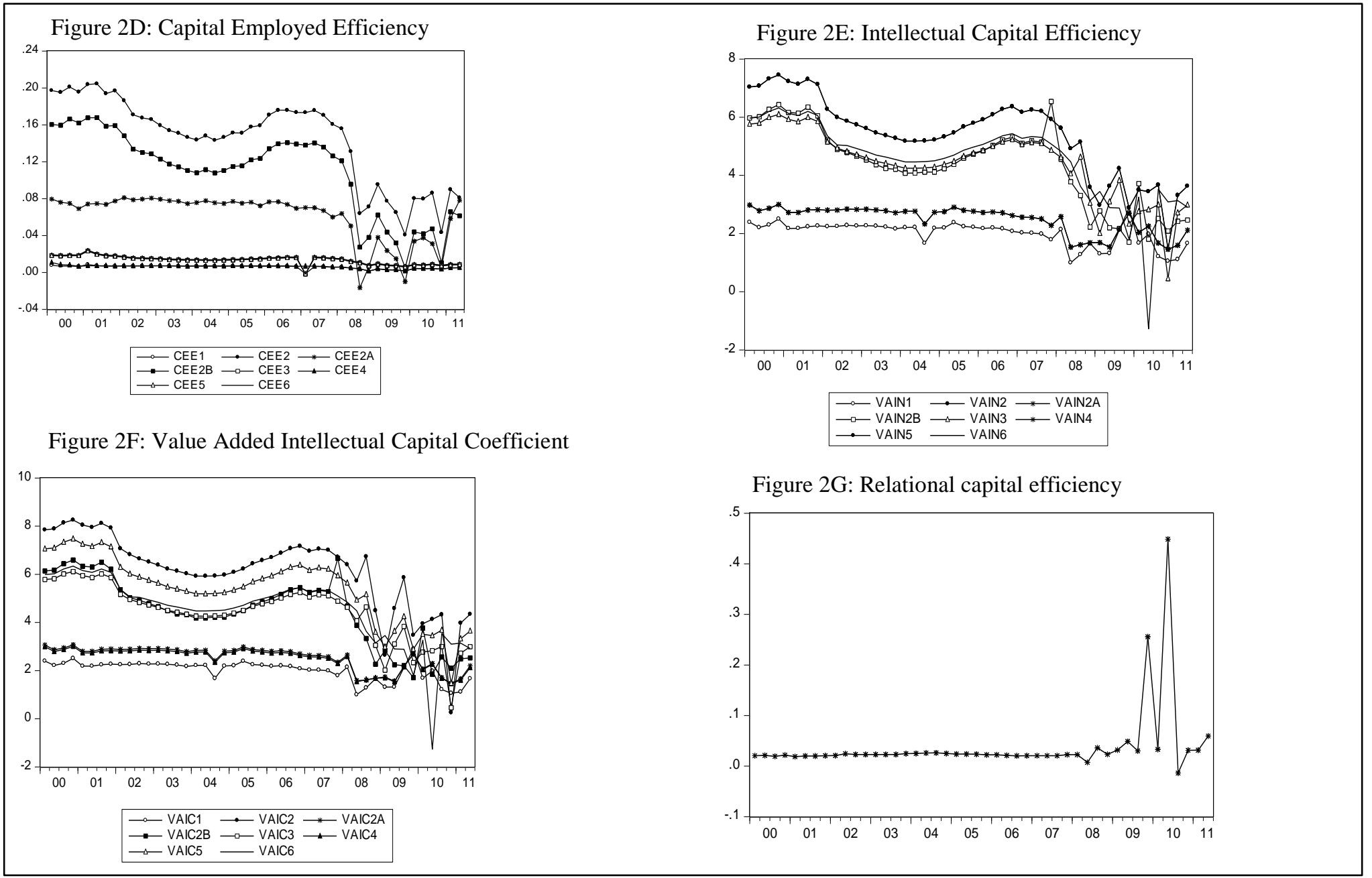


The remaining input variable, CE, of the identified VAIC methods can be categorised under three sections as shown in Table 2. Approaches to compute $C E$ in Methods 1, 3 and 6, and Method 4 would be identical if Method 4 includes financial capital in addition to the current approach to represent physical capital as $C E$. However, Method 2 uses the book value of net assets, which computationally has a lower value than $C E$ in other methods (see Figure 1C). Furthermore, the rest of the descriptive statistics (i.e. standard deviation, skewness and kurtosis) for $C E$ in Table 2 reveal that the distributions of $C E$ in Methods 1, 3, 4, 5 and 6 are very similar.

The remaining input variable, CE, of the identified VAIC methods can be categorised under three sections as shown in Table 2. Approaches to compute $C E$ in Methods 1, 3 and 6, and Method 4 would be identical if Method 4 includes financial capital in addition to the current approach to represent physical capital as $C E$. However, Method 2 uses the book value of net assets, which computationally has a lower value than $C E$ in other methods (see Figure 1C). Furthermore, the rest of the descriptive statistics (i.e. standard deviation, skewness and kurtosis) for $C E$ in Table 2 reveal that the distributions of $C E$ in Methods 1, 3, 4, 5 and 6 are very similar.

Sales, marketing and advertising expenses represents $R C$ in the modified VAIC method (Method 6). $R C$ has a mean of 1.17 with a standard deviation of 3.41.

The mean values of input variables in all VAIC methods are substantially larger than medians, indicating that the sample includes a small number of very large values. Additionally, leptokurtic distributions for input variables of all methods indicate that most of the values are concentrated around the mean (see Table 2).

Reported mean values in Table 2 and Table 3 are substantially higher than medians. Following leptokurtic distributions for input variables of VAIC methods as identified earlier, the values obtained (SC, HCE, SCE, CEE, RCE, VAIN and VAIC) in all VAIC methods persist with leptokurtic distributions. However, certain variables such as HCE in Methods 1, 2a and 4; CEE in all methods, except Method 1; and SCE, VAIN and VAIC in Methods 2, 3, 5 and 6 show a negative skewness. These left skewed distributions indicate that most values for the above variables are higher than the average value whereas certain firms have very low values. This pattern is contrary to the observed positive skewness for related input variables in Table 2.

The most interesting observation in Figures $2 \mathrm{~A}$ to $2 \mathrm{~F}$ is the reflection of the behaviour in Figure 1A. This highlights the dominant role that the $V A$ variable plays 
in determining the IC level. However, RCE has a relatively distinctive behaviour though the volatilities of $V A$ at the latter stage of the sample period and these are reflected in Figure 2G. Further, the same Figures set the upper and lower boundaries for average value creations in the VAIC methods. According to Figures $2 \mathrm{~A}$ to $2 \mathrm{~F}$, Pulic's initial method (Method 1) to measure IC represents the lower boundary for average values of all created values such as SC, HCE, SCE, CEE, VAIN and VAIC. The obvious reason for this pattern is that Pulic's method places $V A$ at a minimum level compared to other methods. Meanwhile, Method 1 inputs $H C$ and $C E$ at the maximum level among the identified VAIC methods. In contrast, Methods 2 and 5 provide the upper boundary for average SC, HCE, SCE, VAIN and VAIC. Method 2 sets the upper limit for $C E E$, which is considerably higher than other methods. The reason for this is that Method 2 includes $V A$ according to the stakeholder theory, which recognises $V A$ at a higher level. Inclusion of net assets as $C E$, a considerably lesser value, compared to including the aggregate value of physical capital and financial capital is the reason for considerably higher values being reported for CEE in Method 2 .

Table 4: Descriptive Statistics of Dependent Variables

\begin{tabular}{lrrrrrrr}
\hline Variable & Mean & \multicolumn{1}{c}{ Median } & \multicolumn{1}{c}{ Max } & \multicolumn{1}{c}{ Min } & SD & \multicolumn{1}{c}{ Skew } & \multicolumn{1}{c}{ Kurtosis } \\
\hline ATO & 0.017 & 0.016 & 0.111 & 0.007 & 0.003 & 3.96 & 73.69 \\
$R O A$ & 0.002 & 0.003 & 0.048 & -0.10 & 0.004 & -8.81 & 163.51 \\
$R O E$ & 0.017 & 0.03 & 6.09 & -12.75 & 0.199 & -37.62 & 2514 \\
$M B$ & 0.013 & 0.014 & 0.074 & 0.001 & 0.006 & -3.25 & 44.52 \\
\hline
\end{tabular}

Note: Number of observations is 8,786

Minimum values related to profitability ( $R O A$ and $R O E$ ) of sample firms in Table 4 reveal that some firms report losses. Meanwhile, all performance indicators have leptokurtic distributions, which prove that a majority of values of these variables gather around the mean values. However, right skewed distribution for $A T O$ indicates that most of the values of these variables are lower than the average even though some higher positive amounts do exist. This pattern varies in the distribution for $R O A, R O E$ and $M B$ as they have left skewed distributions.

\section{Correlation Analysis}

The key observation related to correlations of IC measured under different VAIC methods and corporate performance is their identical nature in most of the cases (see Table 5). This pattern is reported despite the fact that the processes of obtaining IC values in different methods are conceptually and computationally different. However, 
Pulic's original VAIC framework (Method 1) has an inconclusive association between IC and ROA. Commenting on the methods that provide improved associations, Methods 2 and 5 show marginally higher associations of IC with $A T O, R O A, R O E$, and $M B$. It should be further noticed that all associations of IC and firm performance are weak positive despite the correlations for Methods $2 b$ and 5 with ROA; Methods $2 a$, $2 b$ and 5 with $R O E$; and Methods $2 b$ and 5 with $M B$ are slightly higher than that of other methods.

Table 5: Correlation between IC and Firm Performance

\begin{tabular}{lllllllll}
\hline Variable & $M-1$ & $M-2$ & $M-2 a$ & $M-2 b$ & $M-3$ & $M-4$ & $M-5$ & $M-6$ \\
\hline$A T O$ & $0.032^{\mathrm{a}}$ & $0.066^{\mathrm{a}}$ & $0.051^{\mathrm{a}}$ & $0.104^{\mathrm{a}}$ & $0.082^{\mathrm{a}}$ & $0.049^{\mathrm{a}}$ & $0.106^{\mathrm{a}}$ & $0.061^{\mathrm{a}}$ \\
$R O A$ & 0.013 & $0.03^{\mathrm{a}}$ & $0.025^{\mathrm{b}}$ & $0.039^{\mathrm{a}}$ & $0.035^{\mathrm{a}}$ & $0.025^{\mathrm{b}}$ & $0.045^{\mathrm{a}}$ & $0.024^{\mathrm{b}}$ \\
$R O E$ & $0.090^{\mathrm{a}}$ & $0.096^{\mathrm{a}}$ & $0.180^{\mathrm{a}}$ & $0.160^{\mathrm{a}}$ & $0.118^{\mathrm{a}}$ & $0.142^{\mathrm{a}}$ & $0.158^{\mathrm{a}}$ & $0.080^{\mathrm{a}}$ \\
$M B$ & $0.039^{\mathrm{a}}$ & $0.070^{\mathrm{a}}$ & $0.068^{\mathrm{a}}$ & $0.094^{\mathrm{a}}$ & $0.084^{\mathrm{a}}$ & $0.067^{\mathrm{a}}$ & $0.111^{\mathrm{a}}$ & $0.056^{\mathrm{a}}$ \\
\hline
\end{tabular}

Notes: $1 .{ }^{a}$ and ${ }^{b}$ denote significance levels $p<0.01$ and $p<0.05$, respectively.

2. Number of observations is 8,786

\section{Regression Results}

Results of the above correlation analysis constitute the first approach to assess the associations between selected variables. Next, the study continues to test the impact of IC on firm performance using constructed linear multiple regression model (Model 1). Before performing the regression analysis, the correlation coefficients between explanatory variables were analysed to ascertain the absence of the multicollinearity problem. In this respect, coefficients of all possible associations between explanatory variables of the model were observed. The association between IC and CEE of all VAIC methods in the model ranged between 0.028 (in Method O) and 0.21 (in Method 2). These correlations do not provide evidence of strong correlations between explanatory variables. Hence, it can be presumed that there is an absence of the multicollinearity problem in this analysis. The Im, Pesaran and Shin test (Im, Pesaran, \& Shin, 2003) was applied to check the stationarity of the data before carrying out the regression analysis. Results of the test led to the rejection of the null hypothesis of the unit-root for all related variables in regression models, except for $A T O$ and $M B$. However, these variables are stationary at the first difference level though the remaining variables are stationary at levels.

Before assessing the validity of fixed effects models, a required test was carried out to check whether fixed effects (i.e. different constants for each group) should indeed be included in the models. In this respect, the standard $F$-test was used to check the validity of fixed effects models against the simple pooled ordinary least squares 
(OLS) method. Based on the reported higher values for $F$-statistic than the $F$-critical value, the null hypothesis that all the constants are the same (homogeneity); $\mathrm{H}_{0}: \mathrm{a}_{1}=$ $\mathrm{a}_{2}=\ldots=\mathrm{a}_{\mathrm{N}}$ ' has been rejected and the application of fixed effects models proved appropriate than pooled OLS for this analysis. Furthermore, both fixed and random effects models were applied for panel data used in this analysis to find better estimates. Estimates of both fixed and random effects models were affirmed through employing Hausman Specification test (Hausman, 1978). In instances where both models were found significant, then the results of the random effects model were taken into consideration in selecting the most suitable model.

Table 6 summarises the estimates of Model 1. The impact of IC and physical capital (CEE) on firm performance is presented separately under productivity (ATO), profits on assets $(R O A)$, profits on equity $(R O E)$ and market valuation $(M B)$ models in panel A, B, C and D, respectively.

Coefficients of both IC $\left(\beta_{11}\right)$ and CEE $\left(\beta_{21}\right)$ of Methods 2, $2 a$ and $2 b$ in panel A provide statistical evidence for a significantly positive influence from both the variables on productivity. Moreover, the evidence indicates that reported coefficients and their signs are consistent with the assumptions of IC theory and Resource-based View. According to the IC theory, IC resources of the firm influence positively on firm performance. $R B V$ assumes both tangible and intangible assets are drivers of firm performance. IC computed through Method 2 provides very little improved results in terms of the level of significance for both explanatory variables.

Following relatively improved estimates as mentioned above, results based on Methods 3 and 5 also show a significantly positive relationship between IC and productivity though the evidence is inconclusive for CEE. Deviating from the evidence shown in panel A, panel B of the Table does not present evidence for any method that corresponds with the theoretical assumptions of both IC theory and $R B V$. However, estimates based on Methods 5, 3 and 2 were derived partially corroborating associations with the above theories as VAIN in each method are significantly positively associated with ROA. In contrast, VAIN of Method 4 has a significantly negative relationship with $R O A$ along with a statistically significant positive influence from $C E E$. The adjusted $R^{2}$ and $F$ - statistic related to Method 4 are very much higher than other competing methods. This indicates that the explanatory power and the overall efficiency of the model are much higher if independent variables are measured using Method 4. However, it provides a completely different relationship between IC and $R O A$ as expected in the IC theory. 
Table 6: Estimates of the Model 1 (t-statistics are in Parentheses)

\begin{tabular}{|c|c|c|c|c|c|c|c|c|}
\hline \multicolumn{9}{|c|}{$\begin{array}{l}\text { Model 1: } Y_{i t}=\beta_{01}+\beta_{11} V A I N_{i t}+\beta_{21} C E E_{i t}+\varepsilon_{i t} \\
\text { Panel A: Productivity }(A T O)\end{array}$} \\
\hline & $M-1^{\mathrm{R}}$ & $M-2^{\mathrm{R}}$ & $M-2 \mathrm{a}^{\mathrm{R}}$ & $M-2 \mathrm{~b}^{\mathrm{R}}$ & $M-3^{\mathrm{R}}$ & $M-4^{\mathrm{F}}$ & $M-5^{\mathrm{R}}$ & $M-6^{\mathrm{R}}$ \\
\hline$\beta_{01}$ & $-0.0002^{\mathrm{a}}$ & $-0.0003^{\mathrm{a}}$ & $-0.0002^{\mathrm{a}}$ & $-0.0002^{\mathrm{a}}$ & $-0.0002^{\mathrm{a}}$ & $-0.0003^{\mathrm{a}}$ & $-0.0002^{\mathrm{a}}$ & $-0.0002^{\mathrm{a}}$ \\
\hline$\beta_{11}$ & $\begin{array}{r}0.00001 \\
(1.64)\end{array}$ & $\begin{array}{r}0.0001^{\mathrm{b}} \\
(2.20)\end{array}$ & $\begin{array}{r}0.0001^{\mathrm{b}} \\
(2.10)\end{array}$ & $\begin{array}{r}0.0001^{\mathrm{b}} \\
(2.06)\end{array}$ & $\begin{array}{r}0.0001^{\mathrm{b}} \\
(2.24)\end{array}$ & $\begin{array}{r}0.00001 \\
(1.34)\end{array}$ & $\begin{array}{r}0.0001^{\mathrm{a}} \\
(2.67)\end{array}$ & $\begin{array}{r}0.00001 \\
(1.18)\end{array}$ \\
\hline$\beta_{21}$ & $\begin{array}{r}0.0029^{c} \\
(1.93)\end{array}$ & $\begin{array}{r}0.0004^{\mathrm{a}} \\
(2.96)\end{array}$ & $\begin{array}{r}0.0003^{\mathrm{c}} \\
(1.92)\end{array}$ & $\begin{array}{r}0.0004^{\mathrm{a}} \\
(2.83)\end{array}$ & $\begin{array}{r}0.0007 \\
(1.02)\end{array}$ & $\begin{array}{r}0.030^{\mathrm{b}} \\
(2.01)\end{array}$ & $\begin{array}{r}0.0006 \\
(0.98)\end{array}$ & $\begin{array}{r}0.0006 \\
(1.03)\end{array}$ \\
\hline $\operatorname{Ad} R^{2}$ & 0.03 & 0.03 & 0.03 & 0.03 & 0.03 & 0.02 & 0.03 & 0.03 \\
\hline stat & $6.74^{\mathrm{a}}$ & $6.95^{\mathrm{a}}$ & $6.80^{\mathrm{a}}$ & $6.92^{\mathrm{a}}$ & $6.73^{\mathrm{a}}$ & $1.70^{\mathrm{a}}$ & $6.78^{a}$ & $6.64^{\mathrm{a}}$ \\
\hline
\end{tabular}

Panel B: Profitability $(R O A)$

\begin{tabular}{lrrrrrrrr} 
& $M-1^{\mathrm{F}}$ & $M-2^{\mathrm{F}}$ & $M-2 \mathrm{a}^{\mathrm{F}}$ & $M-2 \mathrm{~b}^{\mathrm{F}}$ & $M-3^{\mathrm{F}}$ & $M-4^{\mathrm{F}}$ & $M-5^{\mathrm{F}}$ & $M-6^{\mathrm{F}}$ \\
\hline$\beta_{01}$ & $0.001^{\mathrm{a}}$ & $0.001^{\mathrm{a}}$ & $0.001^{\mathrm{a}}$ & $0.001^{\mathrm{a}}$ & $0.001^{\mathrm{a}}$ & $-0.0008^{\mathrm{a}}$ & $0.001^{\mathrm{a}}$ & $0.001^{\mathrm{a}}$ \\
$\beta_{11}$ & 0.00001 & $0.0001^{\mathrm{a}}$ & 0.00001 & $0.0001^{\mathrm{c}}$ & $0.0001^{\mathrm{b}}$ & $-0.0001^{\mathrm{b}}$ & $0.0001^{\mathrm{b}}$ & 0.00001 \\
& $(0.71)$ & $(2.60)$ & $(1.06)$ & $(1.87)$ & $(2.18)$ & $(-2.03)$ & $(2.31)$ & $(1.56)$ \\
$\beta_{21}$ & 0.005 & 0.0001 & 0.0003 & 0.0002 & 0.0001 & $0.39^{\mathrm{a}}$ & 0.001 & 0.001 \\
& $(1.24)$ & $(0.52)$ & $(0.80)$ & $(0.64)$ & $(1.35)$ & $(7.17)$ & $(1.36)$ & $(1.36)$ \\
Ad $R^{2}$ & 0.07 & 0.07 & 0.07 & 0.07 & 0.07 & 0.27 & 0.07 & 0.07 \\
$F$-stat & $4.09^{\mathrm{a}}$ & $4.1^{\mathrm{a}}$ & $4.09^{\mathrm{a}}$ & $4.10^{\mathrm{a}}$ & $4.10^{\mathrm{a}}$ & $13.7^{\mathrm{a}}$ & $4.1^{\mathrm{a}}$ & $4.09^{\mathrm{a}}$
\end{tabular}

Panel C: Profitability $(R O E)$

\begin{tabular}{lrrrrrrrr} 
& $M-1^{\mathrm{R}}$ & $M-2^{\mathrm{F}}$ & $M-2 \mathrm{a}^{\mathrm{F}}$ & $M-2 \mathrm{~b}^{\mathrm{F}}$ & $M-3^{\mathrm{R}}$ & $M-4^{\mathrm{F}}$ & $M-5^{\mathrm{F}}$ & $M-6^{\mathrm{R}}$ \\
\hline$\beta_{01}$ & $0.005^{\mathrm{b}}$ & $-0.12^{\mathrm{a}}$ & $-0.04^{\mathrm{a}}$ & $-0.09^{\mathrm{a}}$ & -0.001 & -0.02 & -0.02 & $0.008^{\mathrm{a}}$ \\
$\beta_{11}$ & $0.003^{\mathrm{a}}$ & -0.00001 & -0.0001 & -0.0008 & $0.003^{\mathrm{a}}$ & 0.004 & $0.006^{\mathrm{b}}$ & $0.0014^{\mathrm{a}}$ \\
& $(7.94)$ & $(-0.37)$ & $(-0.91)$ & $(-1.63)$ & $(9.79)$ & $(1.29)$ & $(2.08)$ & $(6.41)$ \\
$\beta_{21}$ & $0.123^{\mathrm{a}}$ & $0.99^{\mathrm{a}}$ & $1.05^{\mathrm{a}}$ & $0.035^{\mathrm{a}}$ & $0.21^{\mathrm{a}}$ & 4.48 & 0.19 & $0.21^{\mathrm{a}}$ \\
& $(8.52)$ & $(11.28)$ & $(39.55)$ & $(29.54)$ & $(3.91)$ & $(1.36)$ & $(0.97)$ & $(3.90)$ \\
Ad $R^{2}$ & 0.02 & 0.07 & 0.09 & 0.08 & 0.02 & 0.06 & 0.03 & 0.017 \\
$F$-stat & $6.15^{\mathrm{a}}$ & $11.0^{\mathrm{a}}$ & $8.43^{\mathrm{a}}$ & $2.39^{\mathrm{a}}$ & $5.56^{\mathrm{a}}$ & $3.59^{\mathrm{a}}$ & $2.38^{\mathrm{a}}$ & $4.35^{\mathrm{a}}$
\end{tabular}

Panel D: Market valuation $(M B)$

\begin{tabular}{lrrrrrrrr} 
& $M-1^{\mathrm{R}}$ & $M-2^{\mathrm{F}}$ & $M-2 \mathrm{a}^{\mathrm{F}}$ & $M-2 \mathrm{~b}^{\mathrm{F}}$ & $M-3^{\mathrm{R}}$ & $M-4^{\mathrm{F}}$ & $M-5^{\mathrm{R}}$ & $M-6^{\mathrm{R}}$ \\
\hline$\beta_{01}$ & $-0.01^{\mathrm{b}}$ & 0.038 & 0.01 & 0.03 & -0.005 & 0.013 & -0.0001 & $-0.009^{\mathrm{b}}$ \\
$\beta_{11}$ & $-0.001^{\mathrm{c}}$ & -0.001 & -0.0001 & 0.0001 & $-0.002^{\mathrm{a}}$ & -0.001 & $-0.002^{\mathrm{a}}$ & $-0.0008^{\mathrm{b}}$ \\
& $(-1.71)$ & $(-1.25)$ & $(-0.18)$ & $(0.18)$ & $(-2.65)$ & $(-0.84)$ & $(-3.39)$ & $(-2.08)$ \\
$\beta_{21}$ & $-0.42^{\mathrm{c}}$ & -0.333 & $-0.41^{\mathrm{a}}$ & $-0.40^{\mathrm{b}}$ & -0.09 & -3.96 & -0.088 & -0.091 \\
& $(-1.91)$ & $(-1.59)$ & $(-2.90)$ & $(-2.29)$ & $(-0.94)$ & $(-1.24)$ & $(-0.88)$ & $(-0.95)$ \\
Ad $R^{2}$ & 0.09 & 0.10 & 0.13 & 0.11 & 0.09 & 0.08 & 0.09 & 0.10 \\
$F$-stat & $21.04^{\mathrm{a}}$ & $5.25^{\mathrm{a}}$ & $6.10^{\mathrm{a}}$ & $5.8^{\mathrm{a}}$ & $21.07^{\mathrm{a}}$ & $4.29^{\mathrm{a}}$ & $21.18^{\mathrm{a}}$ & $21.00^{\mathrm{a}}$ \\
\hline
\end{tabular}

Notes: $1 .{ }^{R}$ and ${ }^{F}$ denote that estimates are based on random effects model and fixed effects model, respectively 2. ${ }^{a},{ }^{b}$, and ${ }^{c}$ denote significance levels $p<0.01, p<0.05$ and $p<0.1$, respectively.

3. Regression results for ATO and MB models are based on 8,595 firm-quarters, and ROA and ROE models on 8,786 firm-quarters.

4. Reported t-statistics of fixed effects models are based on White (1980) standard errors 
Unlike in the ATO model, Methods 2, $2 a$ and $2 b$ do not provide supportive evidence for a positive association between IC and $R O E$ despite being the best methods to establish the association between CEE and ROE (see panel C of Table 6). The explanatory variables drawn through Methods 1, 3 and 6 stands as better alternatives, theoretically acceptable as well, to calculate IC and $C E E$ to estimate the association between IC and ROE. In contrast, the estimates based on the variables identified in Method 5 provides only a significantly positive association between IC and ROE, whereas, variables based on Method 4 do not show any conclusive association.

The key observation on coefficients presented under panel D of Table 6 is that all statistically significant coefficients bear negative signs, indicating both IC and physical assets have a negative impact on market valuation $(M B)$. Results based on Methods 5, 3 and 6 (see panel D) provide relatively better evidence compared to other estimates on the association between IC and $M B$. The reported coefficients are significantly negative in these models and there is no evidence to conclude the impact of $C E E$ on $M B$. Alternatively, the associations based on variables in Method 1 show significantly negative coefficients for both the variables.

\section{Discussion and Conclusion}

This study commenced with a review of existing studies (i.e. Pulic, 1998a, 2001, 2002a, b; Firer \& Williams, 2003; Yalama \& Coskun, 2007; Calisir et al., 2010; Komnenic \& Pokrajcic, 2012; Ting \& Lean, 2009; Chen et al., 2005; Tan et al., 2007; Clarke et al., 2011) which adopted the VAIC method to compute IC of the firm. The review enabled the authors to categorise the existing approaches of the VAIC method into five categories (methods). The categorisation was based on the differences in assumptions used in adopting the method for past studies. Furthermore, the study carried out an additional review to highlight the limitations of the VAIC method. A modification for the existing mechanism for computing IC in the VAIC method was then suggested in Method 6. The modification focused on a key omission in the part of value creating agencies of the method. Subsequently, the suggested modification replaced the contemporaneous agreement on human capital, structural capital and relational capital as components of IC (Cabrita \& Bontis, 2008; Nazari \& Herremans, 2007; Tayles et al., 2007) with already amalgamated value creating avenues (i.e. human capital and structural capital as per Bontis, 2004; Edvinsson, 1997; Edvinsson \& Malone, 1997) in the existing VAIC method. This can be considered as a main contribution of this study. The identified inconsistencies and the suggested 
modification were empirically tested to find out the actual impact of them on IC performance estimations, using the data of banking firms listed on the NYSE.

The value addition $(V A)$ which is undoubtedly the predominant variable of the VAIC method, is positioned at the lowest level in Methods $1,2 a$ and 4 as used in Pulic (1998a, 2001, 2002a, b), Ahangar (2011), Yalama and Coskun (2007), and Clarke et al. (2011). These methods adopt VA as suggested in Pulic's basic VAIC method (Pulic, 1998a, 2001, 2002a, b). Results of the current study show that VA in Pulic's basic method places at the lowest level among the identified six different methods in the study. In contrast, the modified VAIC method in the current study (Method 6) places $V A$ at the highest level among all six VAIC methods referred to in this study. The Method 6 includes all possible VA sources (i.e. retained earnings, total staff cost, interest paid, depreciation and amortisation, tax paid and dividends) as identified in the stakeholder theory. Furthermore, the VA of Method 6 stands slightly higher than that of Methods 2, 3 and 5 appear in Firer and Williams (2003), Chen et al. (2005), and Clarke et al. (2011), because Method 6 includes the total staff cost as the VA to employees but the other methods consider only wages and salaries.

Despite the fact that $V A$ has been identified in three different approaches, human capital (HC), another important input variable of the VAIC method, is recognised in two ways. They are; total personnel expenses (Chen et al., 2005), and the total of wages and salaries (Firer \& Williams, 2003). However, the distribution of the two types of $H C$ variables and the correlation between them $(\rho=0.999$ [not tabulated]) indicates that no difference is caused when incorporating $H C$ in the VAIC method using either way. $C E$, the remaining input variable of the VAIC method, is distributed in an identical manner in Methods 1, 3, 4, 5 and 6. The distribution of CE in Method 2 and its Sub-Methods $2 a$ and $2 b$ has a different pattern as these methods include book value of net assets to represents $C E$, which is very much lower than the approach in the other methods. The created values (i.e. SC, HCE, SCE, CEE, VAIN and VAIC) in Pulic's basic method (Method 1) used in Pulic (1998a, 2001, 2002a, b) are reportedly the lowest. The reason for this pattern is that Method 1 includes VA at the minimum level compared to other methods despite inputting $H C$ and $C E$ at the maximum level amongst all VAIC methods. In contrast, Methods 2 and 5 adopted in Firer and Williams (2003) and Clarke et al. (2011), respectively provide the upper boundary for $S C, H C E$, SCE, VAIN and VAIC; and Method 2 sets the upper boundary for CEE. These upper levels are formulated through the inclusion of $V A$ at a higher level in Methods 2 and 5 and by including $C E$ at the lowest level in Method 2. 
Based on correlation analysis, IC value of each VAIC method have significant positive relationships with productivity $(A T O)$, profitability ( $R O A$ and $R O E$ ) and market valuation $(M B)$, except for the association between IC of Method 1 used in Pulic (1998a, 2001, 2002a, b) and ROA. However, the reported correlations are weak positive in each occasion. Nevertheless, IC calculated in Methods 2 and 5 adopted in Firer and Williams (2003) and Clarke et al. (2011) accounts for marginally higher correlations with firm performance. Regression estimates on the impact of IC measured in each method and productivity (ATO) of the firm reveal that both IC and CEE computed using Methods 2, $2 a$ and $2 b$ in Firer and Williams (2003), Ahangar (2011) and Yalama and Coskun (2007), Calisir et al. (2010), Komnenic and Pokrajcic (2012) and Ting and Lean (2009) have a significant positive influence on ATO. In addition to these, IC measured in Methods 3 and 5 in Chen et al. (2005) and Clarke et al. (2011) is associated with ATO in a significant and positive manner as well, though $C E E$ has an inconclusive association. However, the mechanism used in Methods 2, $2 a$ and $2 b$ to compute $C E E$ needs to be understood before using them to compute IC and CEE. The estimated impact of IC on ROA by drawing explanatory variables through Methods 2, 3 and 5 in Firer and Williams (2003), Chen et al. (2005) and Clarke et al. (2011) indicate that estimated effects are partially corroborated with theoretical assumptions of the IC theory. In this respect, only IC is related to ROA in a significant and positive manner and the effect of $C E E$ is inconclusive. In contrast, IC of Method 4 (Tan et al., 2007) has a significant negative impact on ROA. Hence, it is worthwhile to note that inconsistencies of the VAIC method cause different effects on the ROA association. Methods 1, 3 and 6 are appropriate alternatives to calculate IC and $C E E$ for the ROE model because both variables influence ROE significantly and positively. In contrast, computation of IC and CEE variables using Method 4 seems to be least effective for the ROE model. Method 2 along with its sub-methods calculates variables in a way that it reports a strong association between $C E E$ and $R O E$ but not a conclusive association between IC and ROE. However, all the reported significant influences of IC on $M B$ are negative and IC in each occurrence is computed through Methods 1, 3, 5 and 6. The study is novel in its effort to test empirically the impact of varied applications of the VAIC method on the relationship between IC and firm performance, and it further suggests modifying the present VAIC method to match with theoretically agreed value compositions of IC.

This study is not without its limitations. The study considered only the varied applications of the VAIC method for measuring IC and ignored other methods to measure IC as they are different from each other both conceptually and 
computationally. Since the study considered only selected main deviating applications of the VAIC it ignores some minor differences of the VAIC applications. Hence, future research can be carried out to address the above limitations. Further, the present study did not include control variables in the regression model. Therefore, future researchers may include possible control variables such as firm size and firm leverage in adopting the regression model of this study specially in estimating the contemporaneous relationship between IC and firm performance.

\section{Declaration of Conflicting Interests}

The authors declared no potential conflicts of interest with respect to the research, authorship, and publication of this article.

\section{References}

Abdulsalam, F., Al-Qaheri, H., \& Al-Khayyat, R. (2011). The intellectual capital performance of Kuwaiti banks: An application of VAIC model. iBusiness, 3, 8896. doi:10.4236/ib.2011.31014

Abeysekera, I. (2003). Intellectual Accounting Scorecard - Measuring and reporting intellectual capital. Journal of American Academy of Business, 3(1\&2), 422-427.

Abeysekera, I. (2007). Intellectual capital reporting between a developing and developed nation. Journal of Intellectual Capital, 8(2), 329-345. doi:10.1108/14691930710742871

Ahangar, R. G. (2011). The relationship between intellectual capital and financial performance: An empirical investigation in an Iranian company. African Journal of Business Management, 5(1), 88--95. doi:10.5897/AJBM10.712

Alhassan, A. L., \& Asare, N. (2016). Intellectual capital and bank productivity in emerging markets: Evidence from Ghana. Management Decision, 54(3), 589609. doi:10.1108/MD-01-2015-0025

Al-Twaijry, A. (2009). Intangible assets and future growth: Evidence from Japan. Asian Review of Accounting, 17(1), 23-39. doi:10.1108/13217340910956496

Amir, E., \& Lev, B. (1996). Value -relevance of non-financial information: The wireless communications industry. Journal of Accounting and Economics, 22(13), 3-30. doi:10.1016/S0165-4101(96)00430-2

Andriessen, D. (2004). Making sense of intellectual capital: Designing a method for the valuation of intangibles. Burlington, MA: Elsevier Butterworth-Heinemann. Appuhami, B. (2007). The impact of intellectual capital on investors' capital gains on shares: An empirical investigation of Thai banking, finance and insurance sector. International Management Review, 3(2), 14-25. 
Bala, A. J., Raja, A. S., \& Dandgo. K. I. (2019). The mediating effect of intellectual capital on corporate governance and performance of conglomerates in Nigeria. SEISENSE Journal of Management, 2(3), 16-29. doi:10.33215/sjom.v2i3.109

Bontis, N. (2001). Assessing knowledge assets: A review of the models used to measure intellectual capital. International Journal of Management Reviews, 3(1), 41-60. doi:10.1111/1468-2370.00053

Bontis, N. (2004). National intellectual capital index: A united nations initiative for the Arab region. Journal of Intellectual Capital, 5(1), 13-39. doi:10.1108/14691930410512905

Bontis, N., Janosevic, S., \& Dzenopoljac, V. (2015). Intellectual capital in Serbia's hotel industry. International Journal of Contemporary Hospitality Management, 27(6), 1365-1384. doi:10.1108/IJCHM-12-2013-0541

Bontis, N., Keow, W. C. C., \& Richardson, S. (2000). Intellectual capital and business performance in Malaysian industries. Journal of Intellectual Capital, 1(1), 85100. doi:10.1108/14691930010324188

Bornemann, M. (1999). Potential of value systems according to the VAIC method. International Journal of Technology Management, 18(5), 463-475. doi:10.1504/IJTM.1999.002781

Bourne, M., Mills, J., Wilcox, M., Neely, A., \& Platts, K. (2000). Designing, implementing and updating performance measurement systems. International Journal of Operations and Production Management, 20(7), 754-771. doi:10.1108/01443570010330739

Cabrita, M. D. R., \& Bontis, N. (2008). Intellectual capital and business performance in the Portuguese banking industry. International Journal of Technology Management, 43(1-3), 212-237. doi:10.1504/IJTM.2008.019416

Calisir, F., Gumussoy, C. A., Bayraktaroglu, A. E., \& Deniz, E. (2010). Intellectual capital in the quoted Turkish ITC sector. Journal of Intellectual Capital, 11(4), 537-553. doi:10.1108/14691931011085678

Chan, K. H. (2009). Impact of intellectual capital on organizational performance: An empirical study of companies in the Hang Seng Index (part 1). The Learning Organization, 16(1), 4-21. doi:10.1108/09696470910927641

Chang, W. S., \& Hsieh, J. J. (2011). Intellectual capital and value creation - Is innovation capital a missing link. International Journal of Business and Management, 6(2), 3-12. doi:10.5539/ijbm.v6n2p3

Chen, M-C., Cheng, S-J., \& Hwang, Y. (2005). An empirical investigation of the relationship between intellectual capital and firms' market value and financial performance. Journal of Intellectual Capital, 6(2), 159-176. doi:10.1108/14691930510592771 
Chu, S. K. W., Chan, K. H., \& Wu, W. W. Y. (2011). Charting intellectual capital performance of the gateway to china. Journal of Intellectual Capital, 12(2), 249276. doi:10.1108/14691931111123412

Chung, K.H., \& Pruitt, S.W. (1994). A simple approximation of Tobin's q. Financial Management, 23, 70-74. doi:10.2307/3665623

Clarke, M., Seng, D., \& Whiting, R. H. (2011). Intellectual capital and firm performance in Australia. Journal of Intellectual Capital, 12(4), 505-530. doi:10.1108/14691931111181706

Davis, J. H., Schoorman, F. D., \& Donaldson, L. (1997). Towards a stewardship theory of management. Academy of Management Review, 22(1), 20-47. doi:10.5465/amr.1997.9707180258

Dawes, J. (2000). Market orientation and company profitability: Further evidence incorporating longitudinal data. Australian Journal of Management, 25, 173-200. doi: $10.1177 / 031289620002500204$

D'Hulster, K. (2009). The leverage ratio. Retrieved from www.worldbank.org/financialcrisis/pdf/levrage-ratio-web.pdf

Dorweiler, V., \& Yakhou, M. (2005). A scorecard on intellectual capital performance in the economy. The Journal of American Academy of Business, 7(1), 322-326.

Dumay, J. C. (2012). Grand theories as barriers to using IC concepts. Journal of Intellectual Capital, 13(1), 4-15. doi:10.1108/14691931211196187

Dumay, J., C., \& Tull, J. A. (2007). Intellectual capital disclosure and price-sensitive Australian stock exchange announcements. Journal of Intellectual Capital, 8(2), 236-255. doi:10.1108/14691930710742826

Dzinkowski, R. (2000). The measurement and management of intellectual capital: An introduction. Management Accounting: Magazine for Chartered Management Accountants, 78(2), 32-36.

Edvinsson, L. (1997). Developing capital at Skandia. Long Range Planning, 30(3), 366-373. doi:10.1016/S0024-6301(97)00016-2

Edvinsson, L., \& Malone, M. (1997). Intellectual capital: Realizing your company's true value by finding its hidden brainpower. New York: Harper Business.

El-Tawy, N., \& Tollington, T. (2010). Applying artefact-based criteria to the recognition of "organizational" assets. Journal of Intellectual Capital, 11(4), 451480. doi:10.1108/14691931011085632

Firer, S., \& Williams, S. M. (2003). Intellectual capital and traditional measures of corporate performance. Journal of Intellectual Capital, 4(3), 348-360. doi:10.1108/14691930310487806

Forte, W., Tucker, J., Matonti, G., \& Nicolò, G. (2017). Measuring the intellectual capital of Italian listed companies. Journal of Intellectual Capital, 18(4), 710732. doi:10.1108/JIC-08-2016-0083 
Frankel, R., \& Lee, C. M. C. (1998). Accounting valuation, market expectation, and cross-sectional stock returns. Journal of Accounting and Economics, 25, 283-319. $\mathrm{v} 10.1016 / \mathrm{S} 0165-4101(98) 00026-3$

Gangi, F., Salerno, D., Meles, A., \& Daniele, L. M. (2019). Do corporate social responsibility and corporate governance influence intellectual capital efficiency? Sustainability, 11(7), 1-25. doi:10.3390/su11071899

Gelb, D. S., \& Siegel, P. (2000). Intangible assets and corporate signalling. Review of Quantitative Finance and Accounting, 76(2), 307-323. doi:10.1023/A:1012046823636

Ghosh, S., \& Mondal, A. (2009). Indian software and pharmaceutical sector IC and financial performance. Journal of Intellectual Capital, 10(3), 369-388. doi:10.1108/14691930910977798

Ghosh, D., \& Wu, A. (2007). Intellectual capital and capital markets: Additional evidence. Journal of Intellectual Capital, 8(2), 216-235. doi:10.1108/14691930710742817

Goebel, V. (2015). Estimating a measure of intellectual capital value to test its determinants. Journal of Intellectual Capital, 16(1),101-120. doi:10.1108/JIC$\underline{12-2013-0118}$

Goh, P. C. (2005). Intellectual capital performance of commercial banks in Malaysia. Journal of Intellectual Capital, 6(3), 385-396. doi:10.1108/14691930510611120

Goh, P. C., \& Lim, K. P. (2004). Disclosing intellectual capital in company annual reports: evidence from Malaysia. Journal of Intellectual Capital, 5, 500-510. doi:10.1108/ 14691930410550426

Guthrie, J., Petty, R., \& Johanson, U. (2001). Sunrise in the knowledge economy: Managing, measuring and reporting intellectual capital. Accounting, Auditing and Accountability Journal, 14(4), 365-385. doi:10.1108/EUM0000000005869

Hasan, R., Mohammad, N., \& Alam, M. (2017). Impact of intellectual capital on profitability - Conventional versus Islamic banks. Journal of Accounting, Finance and Auditing Studies, 3(2), 64-80.

Hansen, G. S., \& Wernerfelt, B. (1989). Determinants of firm performance: The relative importance of economic and organizational factors. Strategic Management Journal, 10(5), 399-411. doi:10.1002/smj.4250100502

Hausman, J. A. (1978). Specification tests in econometrics. Econometrica, 46(6), 1251-1271. doi:10.2307/1913827

Hejazi, R., Ghanbari, M., \& Alipour, M. (2016). Intellectual, human and structural capital effects on firm performance as measured by Tobin's Q. Knowledge and Process Management. 23(4), 259-273. doi:10.1002/kpm.1529

Housel, T. J., \& Nelson, S. K. (2005). Knowledge valuation analysis: Applications for organizational intellectual capital. Journal of Intellectual Capital, 6(4), 544557. doi:10.1108/14691930510628816 
Im, K. S., Pesaran, M. H., \& Shin, Y. (2003). Testing for unit roots in heterogeneous panels. Journal of Econometrics, 115(1), 53-74. doi:10.1016/S03044076(03)00092-7

Kamath, G. B. (2007). The intellectual capital performance of Indian banking sector. Journal of Intellectual Capital, 8(1), 96-123. doi:10.1108/14691930710715088

Kamath, G. B. (2008). Intellectual capital and corporate performance in Indian pharmaceutical industry. Journal of Intellectual Capital, 9(4), 684-704. doi:10.1108/14691930810913221

Kamath, G. B. (2015). Impact of intellectual capital on financial performance and market valuation of firms in India. International Letters of Social and Humanistic Sciences, 48, 107-122. doi:10.18052/www.scipress.com/ILSHS.48.107

Kaplan, R. S., \& Norton, D. P. (2004). The strategy-focused organization. Boston: Harvard Business School Press

Komnenic, B., \& Pokrajcic, D. (2012). Intellectual capital and corporate performance of MNCs in Serbia. Journal of Intellectual Capital, 13(1), 106-119. doi:10.1108/14691931211196231

Kujansivu, P., \& Lonnqvist, A. (2007). Investigating the value and efficiency of intellectual capital. Journal of Intellectual Capital, 8(2), 272-287. doi:10.1108/14691930710742844

Laing, G., Dunn, J., \& Hughes-Lucas, S. (2010). Applying the VAIC model to Australian hotels. Journal of Intellectual Capital, 11(3), 269-283. doi:10.1108/14691931011064545

Lev, B. (2001). Intangibles: Management, measurement, and reporting. Washington: The Brookings Institution.

Linda, M. R., Rasyid, R., \& Megawati. (2017). Intellectual capital and firm's performance: An empirical evidence from Islamic Bank in Indonesia. Research \& Reviews: Journal of Social Sciences, 3(3),139-148.

Maditinos, D., Chatzoudes, D., Tsairidis, C., \& Theriou, G. (2011). The impact of intellectual capital on firm's market value and financial performance. Journal of Intellectual Capital, 12(1), 132-151. doi:10.1108/14691931111097944

Maji, S. G., \& Goswami, M. (2016). Intellectual capital and firm performance in emerging economies: The case of India. Review of International Business and Strategy, 26(3), 410-430. doi:10.1108/RIBS-03-2015-0019

Marr, B., Schiuma, G., \& Neely, A. (2004). The dynamics of value creation: Mapping your intellectual performance drivers. Journal of Intellectual Capital, 5(2), 312325. doi:10.1108/14691930410533722

Mavridis, D. G. (2004). The intellectual capital performance of the Japanese banking sector. Journal of Intellectual Capital, 5(1), 92-115. doi:10.1108/ $\underline{14691930410512941}$ 
Mavridis, D. G. (2005). Intellectual capital performance determinants and globalization status of Greek listed firms. Journal of Intellectual Capital, 6(1), 127-140. doi:10.1108/14691930510574708

Mehralian, G., Rajabzadeh, A., Sadeh, M. R., \& Rasekh, H. R. (2012). Intellectual capital and corporate performance in Iranian pharmaceutical industry. Journal of Intellectual Capital, 13(1), 138-158. doi:10.1108/14691931211196259

Moon, C. W., \& Lado, A. A. (2000). MNC- host government bargaining power relationship: A critique and extension within the resource-based view. Journal of Management, 26(1), 85-117. doi:10.1177/014920630002600108

Morariu, C. M. (2014). Intellectual capital performance in the case of Romanian public companies. Journal of Intellectual Capital, 15(3), 392-410. doi:10.1108/JIC-05-2014-0061

Nassar, S. (2018). The impact of intellectual capital on firm performance of the Turkish real estate companies before and after the crisis. European Scientific Journal, 14(1), 29-45. doi:10.19044/esj.2018.v14n1p29

Nazari, J. A., \& Herremans, I. M. (2007). Extended VAIC model: Measuring intellectual capital components. Journal of Intellectual Capital, 8(4), 595-609. doi:10.1108/14691930710830774

Ohlson, J. A. (1995). Earnings, book value, and dividends in equity valuation. Contemporary Accounting Research, 11(2), 661-687. doi:10.1111/j.19113846.1995.tb00461.x

Pal, K., \& Soriya, S. (2012). IC performance of Indian pharmaceutical and textile industry. Journal of Intellectual Capital, 13(1), 120-137. doi:10.1108/14691931211196240

Pulic, A. (1998a). Measuring the performance of intellectual potential in knowledge economy. Retrieved from http://www.vaic-on.net

Pulic, A. (1998b). Measuring the performance of intellectual potential in knowledge economy. Paper presented at 2nd World Congress on Measuring and Managing Intellectual Capital, McMaster University, Hamilton.

Pulic, A. (2000a). VAIC- an An accounting tool for IC management. International Journal of Technology Management, 20(5-78), 702-714. doi:10.1504/IJTM.2000.002891

Pulic, A. (2000b). MVA and VAIC analysis of randomly selected companies from FTSE250. Retrieved from http://www.vaic-on.net

Pulic, A. (2001). Value creation efficiency analysis of Croatian banks 1996-2000. Retrieved from http://www.vaic-on.net

Pulic, A. (2002a). National IC-efficiency report of Croatian economy. Retrieved from http://www.vaic-on.net

Pulic, A. (2002b). Do we know if we create or destroy value. Retrieved from http://www.vaic-on.net 
Riahi-Belkaoui, A. (2003). Intellectual capital and firm performance of US multinational firms. Journal of Intellectual Capital, 4(2), 215-226. doi:10.1108/14691930310472839

Rodov, I., \& Leliaert, P. (2002). FiMIAM: Financial method of intangible assets management. Journal of Intellectual Capital, 3(3), 323-336. doi:10.1108/14691930210435642

Roos, J., Roos, G., Dragonetti, N. C., \& Edvinsson, L. (1997). Intellectual capital: Navigating in the new business landscape. Palgrave Macmillan UK.

Sveiby, K. (1997). The new organizational wealth - Managing and measuring knowledge-based assets. San Francisco: Berret-Koehler Publishers, Inc.

Sveiby, K. (2010). Method of measuring intangible assets. Retrieved from http://www.sveiby.com/articles/IntangibleMethods.htm

Shiu, H. J. (2006). The application of value added intellectual coefficient to measure corporate performance: Evidence from technological firms. International Journal of Management, 23(2), 356-365.

Soetanto, T., \& Liem, P. F. (in press). Intellectual capital in Indonesia : Dynamic panel approach. Journal of Asia Business Studies. doi:10.1108/JABS-02-2018$\underline{0059}$

Stahle, P., Stahle, S., \& Aho, S. (2011). Value added intellectual coefficient (VAIC): A critical analysis. Journal of Intellectual Capital, 12(4), 531-551. doi:10.1108/14691931111181715

Tan, H. P., Plowman, D., \& Hancock, P. (2007). Intellectual capital and financial returns of companies. Journal of Intellectual Capital, 8(1), 76-95. doi:10.1108/14691930710715079

Tayles, M., Pike, R. H., \& Sofian, S. (2007). Intellectual capital, management accounting practices and corporate performance. Accounting, Auditing and Accountability Journal, 20(4), 522-548. doi:10.1108/09513570710762575

Ting, I. W. K., \& Lean, H. H. (2009). Intellectual capital performance of financial institutions in Malaysia. Journal of Intellectual Capital, 10(4), 588-599. doi: $10.1108 / 14691930910996661$

Tsai, H., \& Hua, M. (2006). Can intellectual capital powerfully explain the stock price of electronic companies? Taiwan Academy of Management Journal, 6(2), 237250

Tseng, D.C.Y., \& Goo, Y.J. J. (2005). Intellectual capital and corporate value in an emerging economy: Empirical study of Taiwanese manufacturers. $R \& D$ Management, 35(2), 187-201. doi:10.1111/j.1467-9310.2005.00382.x

Tseng, K.-A., Lin, C.-I., \& Yen, S.W. (2015). Contingencies of intellectual capitals and financial capital on value creation: moderation of business cycles. Journal of Intellectual Capital, 16(1),156-173. doi:10.1142/S0219649217500174 
Wall, A., Kirk, R., \& Martin, G. (2004). Intellectual capital: Measuring the immeasurable. CIMA Publishing, Elsevier.

White, H. (1980). A heteroskedasticity-consistent covariance matrix estimator and a direct test for heteroskedacity. Econometrica, 5(2), 171-180. doi:10.2307/1912934

Yalama, A., \& Coskun, M. (2007). Intellectual capital performance of quoted banks on the Istanbul stock exchange market. Journal of Intellectual Capital, 8(2), 256271. doi:10.1108/14691930710742835

Yilmaz, I., \& Acar, G. (2018). The effects of intellectual capital on financial performance and market value: Evidence from Turkey. Eurasian Journal of Business and Economics, 11(21), 117-133. doi:10.17015/ejbe.2018.021.07

Zeghal, D., \& Maaloul, A. (2010). Analysing value added as an indicator of intellectual capital and its consequences on company performance. Journal of Intellectual Capital, 11(1), 39-60. doi:10.1108/14691931011013325

Zhicheng, L., Zhuoer, C., Shing, L. T. T., \& Wah, C. S. K. (2016). The impact of intellectual capital on companies' performances: A study based on MAKE Award winners and non-MAKE Award winner companies. Procedia Computer Science, 99, 181-194. doi:10.1016/j.procs.2016.09.110 